\title{
COMO SE PROCESSA A DIALÉTICA CONVERSÃO E TRANSFORMAÇÃO SOCIAL? REFLEXÃO SOBRE UM ESTUDO DO NEOPENTECOSTALIŞMO BRASILEIRO
}

Roberto Dos Santos ${ }^{1}$

\begin{abstract}
A busca de uma linguagem ética comum é inseparável de uma experiência de conversão, pela qual as pessoas e as comunidades se afastam das forças que procuram aprisionar o ser humano na indiferença ou impelem a levantar muros contra o outro ou contra o estrangeiro. O coração de pedra - frio, inerte e indiferente à sorte do próximo e da espécie humana - deve se transformar, sob a ação do Espirito, em um coração de carne, sensível aos apelos da sabedoria, da compaixão, do desejo de paz e da esperança para todos. Essa conversão é a condição para um verdadeiro diálogo. ${ }^{2}$
\end{abstract}

\section{Resumo:}

Este trabalho apresenta os elementos que constituem a estrutura de um artigo cientifico sobre conversão e transformação social a partir do discurso do sujeito coletivo no contexto do neopentecostalismo brasileiro, bem como apresenta de forma praxiológica o resultado da pesquisa empírica. Os estudos aqui apresentados baseiam-se no trabalho da Comunidade de Águas Claras-DF. Os resultados visam expressar o pensamento de uma coletividade, como se ela fosse o emissor de um discurso. Conclui que o trabalho demonstra ser plausível e satisfatório quanto a relação dialética conversão e transformação social.

Palavras-chave: Conversão. Transformação social. Sujeito coletivo. Neopentecostalismo

\begin{abstract}
:
This work presents the elements that constitute the structure of a scientific article on conversion and social transformation based on the discourse of the collective subject in the context of Brazilian neo-Pentecostalism, as well as presenting the result of empirical research in a praxiological way. The studies presented here are based on the work of the Águas Claras-DF Community. The results aim to express the thought of a collectivity, as if it were the emitter of a discourse. It concludes that the work proves to be plausible and satisfactory regarding the dialectical relationship between conversion and social transformation.
\end{abstract}

Keywords: Conversion. Social transformation. Collective subject. Neopentecostalism.

\footnotetext{
${ }^{1}$ Roberto dos Santos é Pós-doutorando em Estudos de Religião pela Universidade Católica Portuguesa (UCP).

2 Comissão Teológica Internacional. In: Em Busca de uma Ética Universal: novo olhar sobre a lei natural. São Paulo, Paulinas, 2009, p. 6.
} 


\section{INTRODUÇÃO}

O propósito do presente estudo é refletir sobre o fenômeno da conversão e transformação social, cuja ancestral presença perpassa historicamente as mais diferentes tradições religiosas, a exemplo do Judaísmo, do Cristianismo e do Islamismo, levando-os a atitudes controvertidas quanto à questão proposta.

A abordagem da conversão no estudo ora proposto, com efeito, tem um recorte peculiar, na medida em que trabalhará no sentido da aproximação dialógica de nexos frasais sensíveis, como processo de transformação social, sujeito coletivo, de uma experiência do neopentecostalismo brasileiro.

O neopentecostalismo, nome atribuído à última grande onda do pentecostalismo, possui um conjunto de representações e práticas bem específicas que o distingue como tal das outras correntes pentecostais. A nosso ver, trata-se de um desdobramento e de uma adaptação da tradição pentecostal, com seu paradigma original, na tradição religiosa brasileira, ao longo do agitado século XX. Tal regra não é nova e nem exclusiva do pentecostalismo brasileiro. Toda religião, de fato, segue a história humana no seu desenvolvimento e nas suas dinâmicas econômica, social e cultural, tecendo com elas relações de troca, de forma que uma influencia a outra na configuração de suas visões e de suas práticas.

O processo de conversão religiosa, segundo Merval Rosa ${ }^{3}$, parece ter certas características comuns. Quase todos os autores que estudam o fenômeno da conversão religiosa reconhecem pelo menos três estágios fundamentais: 0 período da inquietação, a crise propriamente dita e o período de paz que segue uma "solução" do problema espiritual.

A religião, portanto, ao mesmo tempo em que ajuda a construir a sociedade como um todo, é também construída por ela. Os estudos de religião já demonstram isso. Karl Marx ${ }^{4}$, filósofo e economista alemão, fala da influência da produção econômica, que dá o fundamento primeiro da sociedade na produção dos significados e dos seus valores, ou seja, a cultura só pode ser compreendida dentro de cada época histórica. Sob essa mesma referência teórica, encontramos a noção de ideologia, quando os significados culturais ajudam a conversar ou, então, a mudar determinadas situações históricas, de acordo com os interesses das classes dominantes e da capacidade de resistência e organização das classes dominadas.

Sem negar a importância da produção econômica na produção da cultura, Max Weber formulou uma explicação que, poderíamos dizer, expõe o ângulo inverso da relação da religião com a sociedade. Para ele, os valores e as visões de mundo são um elemento fundamental nas configurações econômicas ao longo da história. Ficou conhecida a influência do protestantismo ascético na configuração do capitalismo. Protestantismo ascético e capitalismo teceram, segundo Weber, "afinidades coletivas", ou seja, foram, na verdade, o encontro de duas configurações distintas, mas que, por possuírem elementos de alguma forma afins, somaram forças na produção de uma nova configuração cultural, no

\footnotetext{
${ }^{3}$ ROSA, Merval. Psicologia da Religião. Rio de Janeiro: Casa Publicadora Batista, 1985, p. 134.

${ }^{4}$ WEBER, Max. A Ética Protestante e o Espírito do Capitalismo. 5 ed. São Paulo: Pioneira, 1987, p. 64

${ }^{5}$ MARX, Karl; ENGELS, Friedrich. A sagrada família. São Paulo: Bomtempo, 2003, p.111.
} 
caso o capitalismo.

De qualquer forma, a relação entre a religião e o conjunto da sociedade é uma relação dialética. Uma influencia a outra, construtiva ou negativamente. A religião, enquanto conjunto de representações e práticas sobre o sentido último da sociedade, recebe, consciente ou não, a influência dos modos de cada sociedade viver e produzir sua existência nos diversos espaços e tempos. Por outro lado, as representações religiosas ajudam a organizar a vida social nos seus diversos aspectos. A história das religiões demonstra esse nexo inseparável e ensina-nos a olhar as religiões sempre vinculadas aos contextos em que estão, para podermos entender suas histórias, suas modificações e seus desenvolvimentos.

O neopentecostalismo se "encaixou como uma luva" no Brasil. As condições difíceis do país no plano socioeconômico, um dos piores do mundo, em termos de concentração de renda na mão de poucos, o que, via de consequência, gera uma desigualdade social terrível. Além disso, as péssimas estruturas de saúde pública e de educação, fizeram do Brasil terreno fértil para a semente neopentecostal frutificar com abundância.

Por processo de transformação social será compreendida a dinâmica da transmutação de atores sociais e religiosos, em sua consciência e em sua atitude, provocando uma mudança de equilíbrio existencial, norteada por sua relação com a atividade religiosa, de onde são derivados os valores da fé, cuja codificação mandamental constitui ordenanças capazes de influenciar a alteração de atitudes individuais e grupais.

Quanto à ideia de sujeito coletivo, a acepção segundo a qual será tomada, de maneira característica, tem conexão tanto com a dimensão individual, quanto com a instância coletiva.

Para o fundador da escola francesa de Sociologia, Émile Durkheim ${ }^{6}$, a sociedade sempre prevalece sobre o indivíduo, dispondo de certas regras, normas, costumes e leis que asseguram sua perpetuação. Essas regras e leis independem do indivíduo e pairam acima de todos, formando uma consciência coletiva que dá sentido de integração entre os membros da sociedade. Elas se solidificam em instituições que são a base da sociedade que correpondem, nas palavras de Durkheim, "a toda crença e todo comportamento instituído pela coltividade".

O alemão Max Weber ${ }^{7}$, diferentemente de Durkheim, tem como preocuparação central compreender o indivíduo e suas ações. Por que as pessoas tomam determinadas decisões? Quais são as razões para seus atos? Segundo esse autor, a sociedade existe concretamente, mas não é algo externo e acima das pessoas, e sim o conjunto das ações dos indivíduos relacionandose reciprocamente. Assim, Weber, partindo do indivíduo e de suas motivações, pretende compreender a sociedade como um todo.

De acordo com o sociólogo alemão Norbert Elias ${ }^{8}$, é comum distanciarmos indivíduos e sociedade quando falamos dessa relação, pois parece que julgamos impossível haver, ao mesmo tempo, bem-estar, felicidade individual e uma sociedade livre de conflitos. De um lado, está o pensamento de que as instituições - família, escola e Estado - devem estar a serviço da

\footnotetext{
${ }^{6}$ DURKHEIM, Émile. Educação e sociologia. Lisboa: Edições 70, 2001, p. 47.

7 WEBER, Max. Ação social e relação social. In: FORACH, Marialice Mencarine; MARTINS, J, de Souza. Sociologia e sociedade. São Paulo: Livros Técnicos e Científicos, 1977, p. 139.

${ }^{8}$ ELIAS, Norbert. A sociedade dos indivíduos. Rio de Janeiro: Jorge Zahar, 1994, p. 48.
} 
felicidade e do bem-estar de todos. De outro, a ideia da unidade social acima da vida individual.

Para o francês Pierre Bourdieu ${ }^{9}$, o habitus se apresenta como social e individual ao mesmo tempo e refere-se tanto a um grupo quanto a uma classe e, obrigatoriamente, também ao indivíduo. Segundo Bourdieu, o habitus é estruturado por meio das instituições de socialização dos agentes (família e a escola, principalmente), e é aí que a ênfase na análise do habitus deve ser colocada, pois são essas primeiras categorias e valores que orientam a prática futura dos indivíduos. Esse seria o habitus primário, por isso, mais duradouro mas não congelado no tempo.

Ainda que de formas diferentes e, às vezes, até opostas, os três fundadores da sociologia trataram da religião reconhecendo seu lugar na vida dos grupos humanos, indicando sua dinâmica interna e sua eventual contribuição aos processos de mudança social.

À medida em que se relaciona com pessoas de outros universos de vida, o indivíduo desenvolve um habitus secundário não contrário ao anterior, mas indissociável daquele. Assim, vai constituindo um habitus individual, conforme agrega experiências continuamente. Isso não significa que será uma pessoa radicalmente diferente da que era antes, pois se modifica sem perder suas marcas de origem, de seu grupo familiar ou da classe na qual nasceu. Os conceitos e valores dos indivíduos (sua subjetividade), segundo Bourdieu, têm uma relação muito intensa com o lugar que ocupam na sociedade.

Por evidente, quando o indivíduo emerge para a vida, encontra o social envolvente organizado, mas pode passar a agir promovendo a sua tranformação em uma dialética do sujeito moldado, que se transforma em agente de transmutação. Na hipótese ora em estudo, a comunidade de fé aparece como agente transfigurador, por meio de estímulo e de reforço para provocar as mudanças pretendidas nos indivíduos. O grupo em questão constitui uma realidade, plasmando, por suposto, possibilidades de transfiguração de valores e de atitudes frente às condutas individuais, possuindo vinculação necessária com o fenômeno religioso, cuja essência é de religação de cada um com todos e de todos com Deus.

Estudos de Caso, por sua vez, são os resultados de um esforço de pesquisa empírica, em busca de experiencia de vida, no intuito de recolher materiais substantivos, que venham a ser considerados, quer como afirmadores,quer como negadores, da hipótese geral de que a fé tem o poder de transmutar existencialmente, tanto a consciência, quanto a atitude de indivíduos e grupos sociais. Neste particular, o universo para análise envolverá um grupo de 12 pessoas a serem entrevistadas, de ambos os sexos, na faixa etária de 18 a 75 anos, tipificados como de classe média e integrantes da Comunidade de Águas Claras-DF.

No aspecto metodológico, o presente estudo trabalhará com a entrevista enquanto técnica de pesquisa, visando os resultados precisos, de maneira que, da decodificação compreensiva, por suposto, resulte a unidade da problemática da investigação com a escolha epistemológica e analítica ora proposta. Tratarse-á, portanto, da exposição da problemática da investigação como determinante da eleição metodológica, casando ambas as partes na exposição dos resultados da pesquisa, enquanto possível validação da tessitura científica

${ }^{9}$ BOURDIEU, Pierre. Razões práticas. 4 ed., Campinas: Papirus, 1996, p. 22. 
da presente reflexão sobre o complexo fenômeno do neopentecostalismo.

Tem-se consciência de que se está a trabalhar com o fenêmeno desafiante, que exige pensamento complexo para ser adequadamente abordado. A modernidade caminhou na direção da desconstituição da fé enquanto fenêmeno necessário da experiência humana. $O$ cientificismo pretendeu que a ciência responderia a todos os problemas humanos, tornando desnecessária a sobrevivência do mito, da magia, da religião e da filosofia, enquanto formas de elvaboração do saber social.

No desenvolvimento do presente trabalho, a explicação científica fez-se através de seis capítulos. Trataremos, pois, da introdução; do conceito de conversão nas religiões monoteístas. Religião em movimento: exemplos dos fenômenos das crenças no mundo contemporâneo e uma reflexão sobre a mobilidade religiosa. Considerações sobre três experiências marcantes: Liev Tolstói, Antero de Quental e Joaquim Nabuco. Contribuição significativa para a relação entre neopentecostalismo, conversão e transformação social e da pesquisa empírica.

\section{CONVERSÃO NAS RELIGIÕES MONOTEÍSTAS}

Para discutirmos sobre a conversão religiosa, deve-se levar em conta o momento histórico-social da pesquisa. De acordo com o Censo 2010, os evangélicos representam o grupo que mais cresceu, proporcionalmente, no Brasil, desde o ano 2000 até 2010, passando de 15,4\% da população a 22,2\%. No mesmo período, também aumentaram a proporção daqueles que se designam como "sem religião", de 7,3\% para 8,0\%. Essas mudanças foram acompanhadas por um decréscimo da proporção de católicos, os quais passaram de $73,6 \%$ para $64,6 \%{ }^{10}$

O artigo sobre "Conversão religiosa: buscando significados na religião", autorias de Denis De Freitas e Adriano Furtado Holanda que numa análise qualitativa apontaram aspectos benéficos da religiosidade tais como sentimentos de força, harmonia e felicidade, disseram:

A conversão religiosa é um tema complexo, mas de extrema importância para o estudo do comportamento humano. Todavia, há escassez de materiais de pesquisa, mesmo pelo fato do tema envolver o interesse de diversas ciências e abordagens como psicologia, sociologia, teologia, história, antropologia e filosofia, dentre outras. $\mathrm{O}$ debate sobre o tema tem seus primeiros registros no século XIX, com teóricos como William James e J.H Leuba, que privilegiavam a experiência "interior" do sujeito que se converte. ${ }^{11}$

Em uma perspectiva doutrinária, o complexo fenômeno da conversão, que precisará sempre ser matizado, o que significa? Tem-se-o como:

Mudança de opinião ou passagem de um estado para outro. Mudança

\footnotetext{
10 BRASÍLIA. Instituto Brasileiro de Geografia e Estatística (IBGE). Censo demográfico 2010. Características gerais da população, religião e pessoas com deficiência. Rio de Janeiro: Instituto Brasileiro de Geografia e Estatística/MPOG.

11 FREITAS, Denis de; HOLANDA, Adriano Furtado. Conversão religiosa: buscando significados na religião. Rev. Interinst. Psicol., v. 7, n. 1, p. 93-105, Jun., 2014.
} 
de religião passando de uma para outras. Para os profetas do Antigo Testamento o conteúdo da conversão não se prende à eliminação de faltas rituais ou mesmo morais. Também não se prende primordialmente a reparação de uma injustiça ou erros cometidos. ${ }^{12}$

A primeira aproximação com a ideia de conversão, em consequência, remete para trânsito, alteração, redirecionamento opinativo e/ou de filiação religiosa. O chamamento do Antigo Testamento, pela negativa, permite constatar o que não se encontra presente no problema da conversão: problemas rituais e morais e superação de erros e injustiças. Prossiga-se:

A palavra hebraica corresponde a techuvá - sub - indica volta, mas volta enquanto comportamento ativo. Para compreender melhor o que significa conversão para um judeu devemos tomar a ideia de caminho. O homem que vai na direção errada, ao constatar o seu desvio, volta atrás, refaz o caminho para reencontrar o seu objetivo. Aqui trata-se mais de refazer um caminho do que reparar erros isolados". ${ }^{13}$

Novamente excluída a perspectiva de erro, retorna à conversão o sentido de revisão, retomada e reconsideração. O que deve ser corrigido é o caminho desviante.

Outras perspectivas são possíveis quanto à conversão:

\begin{abstract}
Em outro sentido a Bíblia fala do arrependimento de Deus, significando mudança da mente e nova decisão (Gn 6,6-7, etc). A conversão não é um processo em sentido único. É uma expressão de reciprocidade. Converter-se, quer dizer crer em Deus que foi o primeiro a amar-nos. Deste modo a conversão não é de todo uma aspiração unilateral. Não é apenas esforço da vontade humana, da inteligência e do coração. Não é apenas compromisso de orientar para o auto a humanidade, que tende fortemente para baixo. A conversão é, antes de tudo, aceitação. É o empenho de aceitar a Deus em toda a riqueza da Sua 'volta' ('converter') ao homem, esta conversão é uma Graça. ${ }^{14}$
\end{abstract}

O inusitado da formulação se encontra não na mudança, quer de mente, quer de decisão, mas na proposição de que até em Deus há arrependimento. Do exposto deriva a fixação pioneira do amor divino por seus filhos, cuja conversão representaria a confirmação da bilateralidade, no amor dos filhos para com o Pai. Seria um esforço de ascensão, posto que o converso deixaria, por Graça ou favor divino, de confirmar a queda, caindo novamente, para perseguir a elevação na entrega a Deus. A conversão passaria a ser um fulgurante episódio da teologia da Graça.

De mais a mais, a conversão é um movimento integral do ser, em que tudo que define a pessoa se encontra presente, convergindo em favor de um propósito maior, a saber:

O esforço da inteligência, do coração e da vontade é também indispensável para a dimensão divina da vida na dimensão humana, para perseverar nela. É o empenho de voltar-se para Deus dentro da própria religião que se abraçou. A pregação de Jesus coloca-se na

\footnotetext{
12 SCHLESINGER, Hugo; PORTO, Humberto. Dicionário enciclopédico das religiões. v.1, Petrópolis-RJ: Vozes, 1995, p. 701.

$13 \mathrm{lbid}$.

14 Ibid.
} 
linha profética. Entretanto, ela vai muito além da pregação de João Batista. Ela é muito mais premente. João anuncia que o Reino de Deus já começou (Mc 1,15). Assim a exigência da conversão total já não se localiza no futuro, ainda que próximo, mas no presente. Ela não consiste primordialmente numa volta para trás, mas numa acolhida jubilosa da novidade que surge: a Salvação que Ele anuncia e traz. ${ }^{15}$

Inteligência, coração e vontade, em busca sincrônica, são desafiados, na conversão, a estamparem o divino na dimensão humana, em incessante caminhada de um incansável Sísifo. Como se não bastasse, o desafio da premência significa fomentar a Eternidade no Aqui e no Agora, na plenitude da aceitação construtiva da Salvação segundo o Código Crístico.

A superação das ressalvas e das entrelinhas do contingente, típico do que é prosaico na experiência humana é que precisa de ascensão, configurada na permanente perseguição do encontro com o Absoluto, na simbiose de corpo e de alma, como inteligência, coração e vontade. Converte-se é entregar-se a uma experiência cristocêntrica:

Converte-se para Jesus é acolher Sua mensagem, responder
positivamente ao anúncio do Reino. Jesus exige uma adesão total. Na
linguagem das denominações cristãs de origem calvinista a conversão
indica o ato pessoal de adesão a Cristo e à fé cristã. Ele é exigido de
todos os adultos que querem ser tidos como cristãos, mesmo que
tenham sido educados, desde infância, no cristianismo. Na linguagem
popular, usa-se também a palavra conversão para indicar a passagem
de uma confissão religiosa a outras. ${ }^{16}$

O desafio da conversão, de natureza emblemática, carrega consigo tamanha exigência, que, em Cristo, só pode ser com Cristo e para Cristo, conformando uma entrega existencial de natureza totalizante, em consciência e em atitude, da percepção à vivência, na busca da integralidade do compromisso com a Palavra.

Não se confunde a difundida e combatida prática do proselitismo, que é quase uma empresa de caça e pesca, na cruzada em busca da conquista de adeptos, tão-somente para conduzi-los aos arraiás de "uma outra religião, crença ou doutrina". ${ }^{17} \mathrm{O}$ próprio Judaísmo, que contemplou um momento proselitista na sua história, declinou da proatividade missionária, quando da destruição do Segundo Tempo e da aliança política do Império Romano com a Igreja Católica, ocasião em que foi acentuado o antagonismo entre judeus e conversos, em torno da ocupação imagética dos Templos pela religião emergente. Eles - judeus e cristãos - foram proibidos de casar entre si, o que ensejou a separação e conduziu àqueles ao gueto, embargando qualquer possibilidade de diálogo e de catequese entre ambos. ${ }^{18}$

$\mathrm{Na}$ tradição evangélica, particularmente nas denominações menos tradicionais, existe a cultura do proselitismo, segundo a qual se procura converter o outro, seja qual for a sua religião, quase sempre condenando-a, para realizar a exaltação da própria, como a única verdadeira e salvacionista ${ }^{19}$. Já na vertente

${ }^{15}$ SCHLESINGER, Hugo; PORTO, Humberto. Dicionário enciclopédico das religiões. v.2,

Petrópolis-RJ: Vozes, 1995, p. 2124.

16 Ibid.

17 Ibid.

18 Ibid.

19 lbid. 
católica e ortodoxa, depois do encontro entre o Papa Paulo VI e o Patriarca Atenágoras I, em 1967, ficou acordado que o proselitismo encerrava em si mesmo um profundo desrespeito ao outro, à sua fé e sua forma de culto, deixando de contribuir para o decisivo avanço do espírito ecumênico, que pressupõe o respeito a si e ao outro, no fomento necessário dos mais vastos diálogos interconfessionais, à margem de todo e qualquer anátema. ${ }^{20}$

Registre-se ainda mais que a expressão prosélito, presente no Novo Testamento, era relativa à transição dos pagãos para o judaísmo, tornando-os conversos ou convertidos, chegando mesmo a se encontrar nele a notícia de que os fariseus eram capazes de mover terra e céu com o único intuito de fazer um prosélito ${ }^{21}$ : "Ai de vós, escribas e fariseus, hipócritas! pois que percorreis o mar e a terra para fazer um prosélito; e, depois de o terdes feito, o fazeis filho do inferno duas vezes mais do que vós" (Mt 23,15). No Judaísmo antigo o rabinato dividiu os prosélitos em dois: os de retidão, que eram circuncidados, batizados e que praticavam sacrifícios, cumprindo o Judaísmo na letra; os de porta, que não eram circuncidados, seguiam o Noé nos sete mandamentos e eram mais simples e menos avançados. ${ }^{22}$ Pondere-se que o proselitismo foi até mesmo reconhecido como traço de todo e qualquer judeu, pelo poeta Horácio e que foi no século IV, com os Imperadores cristãos, que se tornou terminantemente proibido. $^{23}$

O islamismo é uma religião surgida na Península Arábica, no começo do século VII, por meio de Muhammad (conhecido em português como Maomé). Essa crença religiosa atualmente é a segunda maior do mundo, possuindo cerca de 1,8 bilhão de fiéis, a maioria deles localizada nos continentes asiático e africano.

Islamismo ou Islã é uma doutrina do monoteísmo, embasada pelos ensinamentos do Alcorão, livro sagrado com as revelações de Alá (Deus).

No conceito islâmico, tornar-se um muçulmano ${ }^{24}$, através da conversão, é uma forma de voltar a um estado anteriormente experimentado. Para eles, todos nascem em total estado de submissão, ou seja, todos nascem muçulmanos, por isso assumem que as pessoas se "revertem" ao aceitarem o Islã como sua religião.

A palavra árabe "Islã" significa "submissão" e é derivada de uma palavra que significa "paz". Como tal, a religião do Islã ensina que para alcançar verdadeira paz de espírito e certeza de coração, devemos nos submeter a Deus e viver de acordo com Sua Lei divinamente revelada.

\section{RELIGIÃO EM MOVIMENTO: EXEMPLOS DOS FENÔMENOS DAS CRENÇAS NO MUNDO CONTEMPORÂNEO E UMA REFLEXÃO SOBRE A MOBILIDADE RELIGIOSA}

\footnotetext{
$20 \mathrm{lbid}$.

$21 \mathrm{lbid}$.

22 Ibid.

${ }^{23}$ HERVIEU-LÉGER, Danièle. O peregrino e o convertido: a religião em movimento.

Petrópolis-RJ: Vozes, 1999, p. 31.

${ }^{24} \mathrm{O}$ significado de ser muçulmano é exatamente o conceito da submissão total à vontade de Deus.
} 
A temática da conversão, como exposta em epígrafe, é indissociável da história do cristianismo, seja porque Jesus Cristo foi um judeu converso, seja porque Paulo de Tarso, o $13^{\circ}$ apóstolo, foi outro que também se converteu, acrescentando à sua experiência a condição de general romano. E sem os dois, o primeiro como mestre espiritual fundante e o segundo como peregrino difusor, simplesmente não haveria Cristianismo. Conforme exposto de maneira precedente, o fenômeno da conversão alcançou Santo Agostinho de Hipona e o pensamento da Reforma Protestante, exprimindo uma continuidade na tragetória do criatianismo em suas diferentes fronteiras.

Na literatura contemporânea, sem lugar à dúvida, Danièle Hervieu-Léger conquistou um notório espaço de destaque quanto à sociologia da religião, seja no aspecto da recepção da ruptura por si provocada, seja pela necessidade de compreendê-la na dimensão critica que suscita, com o livro já clássico, intitulado O Peregrino e o Convertido: a religião em movimento, texto que enfrenta um desafio da expansão pela desinstitucionalização. Trata-se de uma realidade complexa, a ser vivenciada de maneira particular, quanto ao cristianismo, por cada vertente que o define, com as variantes especificas de suas múltiplas denominações. Quanto ao catolicismo, o problema é eloquente, uma vez que foi fundado segundo a tradição da territorialidade, da paróquia, do culto, da hierarquia e dos sacramentos.

Danièle Hervieu-Léger discorreu sobre as identidades religiosas, segundo a perspectiva das dinâmicas que a envolvem, frente a processos de mudança de natureza individualista, em tempos de fragmentação das crenças e de passeadores crentes, que transitam por muitas igrejas, crendo de forma diferente, em meio à crise de confiança nos discursos eclesiásticos.

A socióloga da religião em questão perscrutou como reproduzido o processo de transmissão geracional da fé, em contextos de crise dos canais de diálogo da memória religiosa. Tudo é imediato e transmite a sua presença para o ambiente religioso, fazendo com que o código cristalizado da tradição não mais responda aos anseios virtuais e instantâneos das gerações emergentes, desejosas de novos discursos simbólicos, sem o sinete do controle hierárquico evidente. É de onde nascem outras opções religiosas ou o caminho da irreligião. ${ }^{25}$

O peregrino, para Danièle Hervieu-Léger, com efeito, é a própria expressão do movimento, da passagem, do trânsito, da mudança, que são características da liquidez da modernidade. O melhor retrato está no individualismo do crente sem fixidez, que perpassa comunidades, em uma mobilidade circunstancial, sem que as suas raízes penetrem em nenhuma territorialidade, pois tudo em si é temporário, inclusive, o estar associado a esta ou aquela denominação religiosa, pois a religação será, ao contrário da fé legada pela tradição de família, uma reinvenção momentânea de quem continua em deslocamento, expandindo novas formas de experiência religiosa quanto ao ato de crer. ${ }^{26}$

Já o convertido, para a pensadora francesa, significa um triplo de possibilidades: a uma, a da mudança de religião, por quem estava tradicionalmente vinculado a certa comunidade de fé; a duas, a do indivíduo que não tinha nenhuma religião e se integrou, como devoto, àquela que escolheu pela primeira vez; a três, a do crente que se dissociou da religião a que pertencia

25 lbid., p. 81.

26 Ibid., p. 107. 
de maneira ancestral, retornando, entretanto, de fervorosa maneira, em certo momento de sua existência, para a fonte de fé primeira. ${ }^{27}$

Um outro aspecto versado com muita sutileza por Danièle Hervieu-Léger, sem dúvida, é referente ao crescente processo de redução da experiência religiosa ao indivíduo em si mesmo e à sua busca de sucesso. Resulta o fenômeno, em certo sentido, da redução da modernidade ao indivíduo e seus interesses, levando a que a experiência religiosa, por paradoxal que pareça, seja vivenciada sem religação, sem comunidade, enfim, sem sentimento de pertença, com a redução da fé à agenda subjetiva e de resultados do sujeito sem igreja, sem rebanho e sem conexão com a ideia do povo de Deus. É a fé sem comunidade, centrada naquele que não se divide mais, que é o núcleo em si mesmo. ${ }^{28}$

O ápice da reflexão da pensadora francesa se encontra no debate a respeito da laicização na experiência republicana, advinda da Constituição de 1946, no $2^{\circ}$ Pós-Guerra. A laicidade caminhou para processos de aguda mudança, com a pluralização da experiência da fé, em uma França povoada por milhões e milhões de árabes, ou deles descendentes, que tornaram o Islamismo a segunda religião nacional, perdendo apenas para o Cristianismo, sem o olvido da presença do Judaísmo, de perfil tradicional na realidade gaulesa. Sem nenhuma desconsideração, ao contrário, por parte da socióloga da religião, quanto ao fenômeno das seitas, ali também numerosas, exigindo agora a mediação do Estado, como salvaguarda gestora racional do debate religioso e interconfessional. ${ }^{29}$

É, por todos os títulos, exemplar, a colocação de Danièle Hervieu-Léger quanto aos processos de conversão e do seu significado, quando sentencia:

A mesma lógica aparece nas conversões ao catolicismo, sob as quais existem abordagens biográficas relativamente precisas à disposição. Mas ela atua menos a partir das condições sociais da existência dos interessados do que a partir de situações de desordem individual. ${ }^{30}$

Neste sentido, parece que o converter-se tem relação direta com a esperança de colocar-se de pé, de reconstruir-se em marcha, afinal, de restaurar-se redirecionando-se. Prossegue a socióloga da religião:

Obviamente, estas não são inteiramente separadas das condições sociais dos convertidos, mas elas não se limitam completamente a isso. Isso se revela particularmente das conversões ligadas a um evento trágico da vida pessoal (morte de alguém próximo, destruição, mutilação, estupro, etc). ${ }^{31}$

O forte apelo pessoal do ato de converter-se pode resultar, portanto, de uma experiência extrema, como resposta ao gravame da dor, presente em toda e qualquer vida, pois, segundo os estoicos, não há vida sem dor.

A exegese proposta por Danièle Hervieu-Léger cumpre a regra de que ser sábio é matizar. Neste sentido, não há como deixar de trazer à colação a

${ }^{27}$ HERVIEU-LÉGER, Danièle. O peregrino e o convertido: a religião em movimento.

Petrópolis-RJ: Vozes, 1999, p. 139.

28 Ibid., p. 175.

29 Ibid., p. 117.

$30 \mathrm{lbid}$.

31 Ibid. 
seguinte e reveladora passagem:

A análise de 15 relatos de conversões ao catolicismo mostra que nove das trajetórias descritas comportam, diretamente ou numa relação mais distante com a conversão, um episódio desse gênero, explicitamente associado pelos interessados à ulterior reorganização de sua vida espiritual. ${ }^{32}$

Trata-se, em consequência, de uma estação recorrente nos passos a caminho da conversão, com capacidade transfiguradora da vida na ambiência do espírito. Eis a síntese: "Mas, quer eles estabeleçam uma relação ou não com essa cristalização dramática da desordem vivida, todos os percursos de convertidos são descritos como um caminho de construção pessoal". Ora, com toda certeza, a mensagem final é a de que a conversão, súbita, como a de Paulo $^{33}$ ou processual, como a do vulgo, em qualquer hipótese, é uma energia transfiguradora da existência.

\section{CONSIDERAÇÕES SOBRE TRÊS EXPERIÊNCIAS MARCANTES: LIEV TOLSTÓI, ANTERO DE QUENTAL E JOAQUIM NABUCO}

O debate sobre conversão religiosa tem seus primeiros registros no século XIX, com teóricos como William James e J.H Leuba, que privilegiavam a experiência "interior" do sujeito que se converte ${ }^{34}$. Sendo assim, o interesse não estava nas instituições religiosas, mas, nas palavras de James, "nos sentimentos, atos e experiências de indivíduos em sua solidão, na medida em que se sintam relacionados com o que quer que possam considerar o divino"35. Posteriormente, no século XX, tem-se o avanço da sociologia e da antropologia, cujo interesse se volta para os aspectos psicossociais do fenômeno como movimento para escapar à tendência psicologizante de certas abordagens ${ }^{36}$.

Muito se questiona se o fenômeno religioso é algo universal ao homem. Até o momento, o que pode se afirmar é que existem registros de manifestações religiosas em todas as civilizações já documentadas ${ }^{373839}$. Diante disso, devemos reconhecer sua "grande influência na constituição da subjetividade do indivíduo expressa em crenças, valores, emoções e comportamentos a ela

\footnotetext{
32 HERVIEU-LÉGER, Danièle. O peregrino e o convertido: a religião em movimento.

Petrópolis-RJ: Vozes, 1999, p. 117.

33 TOLSTÓI, Liev. Uma confissão. São Paulo: MC Mundo Cristão, 2017, p. 15.

34 VALLE, E. Conversão: da noção teórica ao instrumento de pesquisa. Revistas Estudos da Religião, n. 2, p. 18-50, 2002.

35 JAMES, W. As variedades da experiência religiosa: um estudo sobre a natureza humana.

São Paulo: Cultrix, 1995, p. 31.

36 VALLE, E. Ibid.

37 JUNG, C. G. Psicologia e Religião. Trad. Pe. Dom M. R. Rocha. Petrópolis: Vozes, 1978.

${ }^{38}$ ALVES, R. O enigma da religião. Petrópolis: Vozes, 1975.

${ }^{39}$ SIQUEIRA, Deis. O labirinto religioso ocidental: da religião à espiritualidade. Do institucional ao não convencional. Soc. estado., Brasília, v. 23, n. 2, p. 425-462, 2008. Doi:

http://dx.doi.org/10.1590/S0102-69922008000200008. Disponível em:

$<$ http://www.scielo.br/scielo.php?script=sci_arttext\&pid=S0102-

69922008000200008\&lng=en\&nrm=iso>. Acesso em: 05 mar. 2020.
} 
relacionados" 40 e, consequentemente, a importância dessa dimensão espiritual para o homem ${ }^{41}$. Destaca-se também "a eficácia da religião em promover comportamentos saudáveis e restringir comportamentos nocivos"42. Segundo Baungart e Amatuzzi, em pesquisa com católicos, a vivência religiosa proporcionou mudanças de comportamento, as quais foram sentidas, pelos participantes, como algo importante para melhora na qualidade de vida à medida que estes modificaram seu olhar em relação ao mundo ${ }^{43}$.

A experiência da conversão é um fenômeno religioso, perpassando hemisférios e latitudes e deixando registros mais do que valiosos, pela exemplaridade neles contida, do que são testemunhas as experiências de Liev Tolstói, na Rússia, de Antero de Quental, em Portugal e de Joaquim Nabuco, no Brasil, como comprovam os elementos expressivos, em seguida chamados à colação. Registre-se que os três conversos em questão, refletindo raízes culturais distintas - eslava, ibérica e tropical - convergiram em torno de uma mudança de consciência e de atitude, frente ao poder imantador da fé, no caso, cristico, mas que poderia ser, no sentido abstrato e fenomênico, de outra qualquer tradição de religiosidade, pois se trata, como fenômeno em si, de constatar que a fé é uma força movente e transfiguradora, suficientemente robusta para a opração da mudança de vida, de caráter exclusivo ou inclusivo, seja de figuras modelares, como as encimadas, seja de atores anônimos, como os pertencentes da Comunidade de Águas Claras - DF.

Liev Tolstói é autor de Uma Confissão, cuja abertura tem uma irrecusável dimensão confessional:

Fui batizado e criado na fé cristã ortodoxa. Foi o que me ensinaram desde a infância e durante toda a adolescência e juventude. Mas, aos 18 anos, quando abandonei o segundo período da Universidade, já não acreditava em mais nada do que me haviam ensinado. ${ }^{44}$

É de se perguntar: por efeito do ambiente universitário racionalista que o célebre escritor perdeu a fé? Ele prosseguiu: "A julgar por certas lembranças, nunca acreditei a sério, apenas confiava no que me ensinavam e no que os adultos professavam, à minha frente; mas essa fé era muito vacilante". ${ }^{45}$ Compreende-se que era uma experiência da fé por tradição, formal e sem raízes na experiência pessoal.

Quando da sua conversão como experiência pessoal profunda, Liev Tolstói confessou estar entre dois abismos: o de baixo e o do alto. Eis as reveladoras palavras:

E sinto que, por causa do pavor, perco o último ponto de apoio e, lentamente, escorrego sobre as costas, cada vez mais para baixo. Só

\footnotetext{
40 HENNING, M. C.; Moré. C. L. O. O. Religião e psicologia: análise das interfaces temáticas. Revista de Estudos da Religião. n. 9, v. 4, p. 84-114, 2009, p. 85.

41 VERGíLIO, S. R. \& Holanda, A. F. Analogias e diferenças entre reuniões mediúnicas espíritas e o atendimento em psicologia clínica. Revista da Abordagem Gestáltica, v. 18, n. 2, p. 173-182, 2010.

42 PAIVA, G. J.; et al. Psicologia da Religião no Brasil: A produção em periódicos e livros.

Psicologia: Teoria e Pesquisa, v. 25, n. 3, p. 441-446, 2009, p. 101.

${ }^{43}$ BAUNGART, T. A; AMATUZZI, M. M. Experiência religiosa e crescimento pessoal: uma compreensão fenomenológica. Revista de Estudos da Religião, 2007.

44 Ibid.

45 Ibid., p. 125.
} 
mais um instante e vou despencar. E então me vem uma ideia: isso não pode ser verdade. É um sonho. Acorde. Tento acordar e não consigo. ${ }^{46}$

A metáfora do infinito dos mundos foi o ponto de mutação crucial da experiência do processo de conversão tolstoiano:

O que fazer, o que fazer? pergunto a mim mesmo e olho para cima. Para cima, também é um abismo. Olho para esse abismo do céu e tento esquecer o abismo de baixo e, de fato, esqueço. $O$ infinito de baixo me repele e me apavora; o infinito do lato me atrai e me sustenta. ${ }^{47}$

Enfim, para o notável escritor chegara o momento da transfiguração pela fé, da transmutação pela conversão:

E vejo que já não estou mais pendurado, e que não estou caindo, mas
sim firmemente apoiado. Eu me pergunto como estou apoiado, me
apalpo, olho em volta e vejo que, embaixo de mim, embaixo do centro
do meu corpo, há uma tira trançada e que eu, olhando para cima, estou
deitado sobre ela num equilíbrio perfeitamente estável e que, já antes,
era só ela que me sustentava. ${ }^{48}$

A fé subjacente esteve no percurso do convertido: Liev Tolstói.

A vivência do autor de Guerra e Paz foi profundamente pessoal e não se confunde em nada com a inquietação psicológica da existência do poeta Antero de Quental, de matiz filosófico, cujo fim trágico o conduziu ao suicídio. Vivendo em um século herdeiro do racionalismo decorrente da Revolução Francesa, o poeta português, integrante de um círculo intelectual inquieto, vinculado à Questão Coimbrã, Antero Tarquínio de Quental de tudo duvidou, até mesmo da verdade da conversão, como deixou estampado, com ardente sentido crítico, no verso fatal do soneto ora chamado à colação:

\section{O CONVERTIDO}

Entre os filhos dum século maldito

Tomei também lugar na ímpia mesa, Onde, sob o folgar, geme a tristeza

Duma ânsia impotente de infinito.

Como os outros, cuspi no altar avito

Um rir feito de fel e de impureza...

Mas, um dia, abalou-se-me a firmeza,

Deu-me rebate o coração contrito!

Erma, cheia de tédio e de quebranto, Rompendo os diques ao represo pranto, Virou-se para Deus minha alma triste!

\footnotetext{
46 Ibid., p. 126.

47 TOLSTÓI, Liev. Uma confissão. São Paulo: MC Mundo Cristão, 2017, p. 126.

48 VIANA, António Manuel Couto. Tesouro da poesia portuguesa: Selecção, prefácio e notas. Lisboa: São Paulo: Verbo, 1984, p. 130.
} 
Amortalhei na fé o pensamento,

E achei a paz na inércia e esquecimento...

Só me falta saber se Deus existe! ${ }^{49}$

Vê-se com nitidez que Antero de Quental considerou a fé o sepulcro do pensamento, retratando, inclusive, a conversão como razão de ser de mais dúvida do que repouso, em sentido diametralmente contrário àquele estampado na vivência singular de Liev Tolstói. De toda meneira, Antero de Quental reflete o racionalismo e o positivismo do espírito de sua época, sem deixar de revelar, entretanto, a sua iquietação intima, visceral, com o fenômeno da divindade, sobre o qual não conseguiu silenciar. É como se se pudesse, recobrar da metáfora do baixo e do alto, argumentar que, no poeta português, o peso de baixo tisnou de dúvida e de angústia, quase descrença torturada, a asa talvez quebrada do alto, como se o realismo de Aristóteles nele, Antero de Quental, comprometesse o idealismo de Platão.

Joaquim Nabuco, por sua vez, foi alguém que, vivido no ambiente patriarcal brasileiro do Engenho Massangana, situado no Cabo de Santo Agostinho, onde seu antepassado João Paes Barreto foi Morgado, respirou a religiosidade tradicional então reinante. A lgreja era uma coluna necessária de sustentação da sociedade brasileira, muitas vezes, erguida dentro do latifúndio escravocrata, ou, outras tantas, no interior das casas-grandes, em forma de capelas, legitimando, em tudo e por tudo, a ordem estabelecida. Sucede que o menino de engenho, deixando o meio rural e ingressando em ambiente universitário, talvez à semelhança do que aconteceu com Liev Tolstói e com Antero de Quental, tenha recebido os influxos do racionalismo definidor da modernidade e do seu cientificismo ${ }^{50}$, afastando-se da fé.

Nas palavras do próprio Joaquim Nabuco, presentes nas páginas imortais de Minha Formação, assim aconteceu:

\begin{abstract}
Nesse tempo, e durante alguns anos, o radicalismo me arrasta; eu sou, por exemplo, dos que tomam parte mais ativa na campanha maçônica de 1873 contra os bispos e contra a igreja. Entro nas ideias de Feijó, de uma Igreja nacional, independente da disciplina Romana; faço conferências, escrevo artigos, público folhetos. ${ }^{51}$
\end{abstract}

Só a caminho do ocaso compreendeu Nabuco o significado das palavras do seu Pai, em 1860, então Senador do Império, ao inventariar em discurso, quais as necessidades prementes do Brasil: "a primeira é a difusão do princípio religioso no interesse da família e da sociedade" 52 , enquanto o filho rebelado, resgatando a si mesmo, argumentava: "Posso dizer, falando a nova gíria científica, que eu não tinha então nada de estático, era todo dinâmico" 53 . Então, a Ciência retirou Joaquim Nabuco da Fé e fomentou o seu reconhecido

\footnotetext{
${ }^{49}$ Consultar a respeito: SALDANHA, Nelson. Teológico, metafísico e positivo.

Filosofia e epistemologia no ocidente moderno. Rio de Janeiro: Academia Brasileira de Letras, 2010, p. 89.

50 NABUCO, Joaquim. Minha formação. Brasília: Edições Câmara, 2019, p. 48.

51 lbid., p. 48.

52 Ibid.

${ }^{53}$ NABUCO, Joaquim. Minha fé. Recife: Fundação Joaquim Nabuco; Massangana, 1985, p. 140.
} 
radicalismo.

Entretanto, no ocaso da vida, o estadista da abolição escreveu Minha Fé - Mysterium Fidei, em que, defendendo a liberdade científica, o convertido retorna ao berço original da experiência religiosa em si revigorada: "aceitei em sua total integridade a fé da minha infância" ${ }^{4}$, em "um quadro de consumada beleza" 55 , pois, "a graça de Deus jamais me abandonara" 56 . Joaquim Nabuco pontificou quanto ao reencontro com a Fé: "O que eu acabava de realizar era a última das deduções do coração" 57 . E mais: "Instado por minha consciência a adotar uma religião, achei-me vinculado à do Cristo e, uma vez cristão, acheime católico" 58 , para "colocar minha morte em conformidade com meu nascimento" 59 , posto que, assim, "restituiria ao infinito a mesma alma que ele me dera"60. De onde a sentença nabuquiana máxima: "Porque, se Deus não existir, não nos decepcionaremos com Ele; mas, se Deus existe, não se decepcionará conosco" ${ }^{61}$. Eis como Joaquim Nabuco se reencontrou com a sobre naturalidade da Fé.

Em síntese, em Liev Tolstói e em Joaquim Nabuco, a conversão foi um fenômeno integral, a transformar subjetividades e atitudes, frente à existência. Enquanto para Antero de Quental, constituiui uma aflitiva realidade, uma torturada situação de um racionalista que esteve prestes a dele declinar, entrangando-se à fé, mas que, saturado de dúvidas racionalistas e positivistas, encontrando a paz em Deus, ainda assim, irrequieto, não cessou de perguntar se Deus existe.

Quanto à comunidade de Águas Claras - DF, sem dúvida, o trabalho social ali desenvolvido permite garantir que o comportamento padrão seja muito mais o relativo à converão integral, no estilo de Liev Tostói e de Joaquim Nabuco, do que a conversão aflitiva e torturada de Antero de Quental.

Os atotes da Comunidade de Águas Claras - DF, caminharam na direção efetiva de uma mudança de consciência e de conduta, em face de sua existência individual e social, permitindo, no sentido fenomenológico, a construção da abstração de que, ainda que considerados os limites do teste empírico ali aplicado, a fé é uma força suficientemente produtora de mudanças subjetivas e objetivas, em todo homem e no homem todo.

\footnotetext{
54 Ibid., p. 140.

55 Ibid., p. 141.

56 lbid., p. 142.

57 lbid.

58 lbid.

59 lbid.

$60 \mathrm{lbid}$.

${ }^{61}$ Consultar a respeito: CORRÊA, Rossini. Teoria da justiça no Antigo Testamento. Brasília: OAB Conselho Federal, 2015, p. 210; CORRÊA, Rossini. Crítica da razão legal. Brasília: OAB Conselho Federal, 2014, p. 388; CORRÊA, Rossini. Jusfilosofia de Deus. Brasília: Editora Primogenitos, 2005, p. 370; CORRÊA, Rossini. Saber direito: tratado de filosofia jurídica. Brasília: Rossini Corrêa, 2011, p. 637; e CORRÊA, Rossini. Reflexões sobre justiça em um mundo em crise: a demanda por direitos fundamentais na era da incerteza. ("Rossini Corrêa concede entrevista a uma jovem jurista").

42. O DSC é uma técnica de análise de dados em pesquisa qualitativa/quantitativa que foca no pensamento ou opinião comum dos sujeitos pesquisados. Dentre os principais operadores metodológicos do DSC, temos: 1) as expressões-chave; 2) as ideias centrais, 3: o discurso do sujeito coletivo. (LEFEVRE, LEFEVRE, 2006).
} 


\title{
5. CONTRIBUIÇÃO SIGNIFICATIVA PARA O ENTENDIMENTO DA RELAÇÃO ENTRE NEOPENTECOSTALISMO, CONVERSÃO E TRANSFORMAÇÃO SOCIAL
}

Neste capítulo, considerando o contexto, impõe-se um questionamento da mais extrema exigência técnica de teor semântico político-ideológico: de que transformação estamos falando? Qual a ressignificação do rótulo transformação social? Notadamente, não estamos concebendo a noção marxista de transformação social que significa "a transformação radical de uma sociedade, isto é revolução", que está sempre ligada à superação de um sistema social por outro, cuja especificação é consequência de um movimento popular ou de uma classe social. Não. Aqui, estamos nos referindo categoricamente a mudanças num sistema subjetivo de crenças, isto é, na alteração da consciência social dos sujeitos individuais. Resumindo, esse é um processo de conversão pessoal dos sujeitos. Portanto, o universo pesquisado (a Comunidade de Águas Claras-DF, que consideramos significativa), cuja amostragem representa o grupo do movimento neopentecostal.

Sociologicamente, tal propósito metodológico, quer significar uma ressocialização dos indivíduos em sujeitos capacitados doravante, a assumir papéis sociais institucionais cristalizados como não mais anômicos nem amorfos, mas agora como agentes sociais sadios e formais.

Nas palavras do doutor Alfredo Teixeira:

\begin{abstract}
Como noutro lugar se mostrou a definição durkheimiana evolui da afirmação geral de que a religião é um sistema de símbolos que exprimem a identidade colectiva para a ideia específica de que a religião é um sistema de crenças e de práticas relativas as coisas sagradas. O sagrado é a ordem que determina os factos sociais, e a religião é a expressão simbólica da solidariedade que permite à sociedade a anomia e ao amorfismo, superando a desordem que permanentemente a ameaça. $\mathrm{Na}$ taxonomia de Durhheim, o sagrado é, assim, o gérmen do profano, mas o profano é a substância de onde brota o sagrado - como a ordem que dá origem à desordem para daí resultar uma ordem renovada. ${ }^{62}$
\end{abstract}

O que está em questão para o sociólogo que estuda a religião são as relações entre religião e processos sociais.

Para Durkheim, a religião e suas cerimônias cumprem um papel social ao colocar várias pessoas coletivamente em uma celebração. $O$ interesse do sociólogo pela religião seria por ela apresentar vários rituais, simbologias e os efeitos que cada uma delas afeta tanto socialmente como emocionalmente.

Antes de ter uma divindade para seguir seus mandamentos, a religião introduz na vida das pessoas um "sistema de crenças e de práticas". Segundo Durkheim, a religião é um fenômeno coletivo, mas não pode haver crenças moralmente impostas se não tiver um caráter sagrado para esses seguidores, fazendo-os distinguir entre sagrados e algo feito individualmente, que a religião seguida não aprova como algo profano.

A ideia de Durkheim é que as pessoas precisam crer em algo para se

62 TEIXEIRA, A. A exterioridade de Deus: uma aproximação à teoria da religião de Régis Debray. Didaskalia, v. 38, n. 2, p. 455-481, 1 jun. 2008, p. 470. 
sentirem completas. Esse é o papel que a religião tem em sociedade, resultando nos sentimentos que são compartilhados por aqueles seguidores de uma mesma religião.

A dualidade do sagrado e do profano para Durkheim é o que faz a religião ter o caráter de uma força moral, as entidades divinas que fazem o seguidor viver sabendo dos limites entre certo e o errado e faz com que a sociedade viva com uma espécie de civilidade, na qual quem não segue o que é sagrado, é punido por Deus.

A academia brasileira tem sido pródiga na produção de estudos do neopentecostalismo, a partir de diferentes abordagens e referenciais teóricos. $O$ crescimento numérico surpreendente desses grupos tem chamado a atenção de estudiosos até de outros países.

Vamos considerar apenas algumas referências bibliográficas, incluindo artigos científicos próximos ao nosso tema, pois ainda não dispomos no Brasil de muitos estudos sobre conversão e transformação social, como tratado em nossa pesquisa.

"A evangelização tem de calar fundo o coração no homem e dos povos. Por isso, sua dinâmica procura a conversão pessoal e a transformação social". ${ }^{63}$

\title{
5.1. O NEOPENTECOSTALISMO
}

Para o estudo desta temática, destacamos:

\begin{abstract}
Embora os termos "neopentecostal" e "neopentecostalismo" já fossem utilizados nos Estados Unidos, a literatura nacional, em especial Mariano (1996 e 1999), associará a terceira onda a esse fenômeno. Em outras palavras, a pressuposição é a de que as características já descritas em epígrafe - em conjunto com uma tendência à gestão econômica empresarial de parte das igrejas criadas no período justificariam a utilização do prefixo "neo" para caracterizar a lógica pentecostal da terceira onda. Devemos, porém, recordar que o termo neopentecostal não é uma categoria "êmica" ou nativa, ou seja, em geral não é utilizado pelos grupos e agregações religiosas. Trata-se de uma categoria analítica, construída no campo da investigação sociológica, que objetiva nomear um conjunto específico de práticas religiosas (e não denominações específicas). Nessa lógica, tem sido utilizada pela literatura da área como um "tipo ideal", no sentido weberiano do termo. ${ }^{64}$
\end{abstract}

Enquanto procedimento heurístico, o tipo ideal é decorrente da história e da sociologia alemãs, talvez existindo a precedência de Ernest-Sombart, no tocante à construção lógica de um modelo de judeu empreendedor como agente responsável pelo advento real e concreto da sociedade capitalista. Neste sentido, quando Max Weber construiu o tipo ideal de ação social responsável pelo advento do capitalismo em torno da ética calvinista, o teria feito em dialogia com Ernest-Sombart, ainda que deslocando para a religião reformada a

63 DOIG, K. Germán. Dicionário Rio Medellín Puebla. São Paulo: Loyola, 1992, p. 111.

64 BRANDÃO, André Augusto Pereira; JORGE, Amanda Lacerda. A recente fragmentação do campo religioso no Brasil: em busca de explicações. Revista de Estudios Sociales, n. 69, p. 83-84, julio-septiembre, 2009. 
responsabilidade pela afirmação do capitalismo. De qualquer sorte, o neopentecostalismo é herdeiro da conexão da religião reformada, reconhecendo a busca e a conquista da riqueza enquanto bênção, graça, ou favor imerecido de Deus. João Calvino reconheceu a ordem material como impura, mas a declarou como necessária de ser enfrentada pelo homem concreto, a responder, como mordomo, pela distinção recebida enquanto agente da prosperidade, ao melhorar as circunstâncias envolventes por meio do trabalho, da poupança, da proatividade, da reinversão, enfim, do progresso enquanto sinal de distinção que todo o crente dizimista deve fomentar, servindo à expansão da Palavra no mundo.

A conversão é um dos grandes temas dos estudos religiosos, tratado pelos pesquisadores teológicos, filosóficos e sociais. Temos aqui uma percepção intrínseca entre neopentecostalismo e conversão:

Recentemente encontram-se autores, como Berger, em ' $O$ dossel sagrado', que trabalha com o conceito de secularização de mundo, apontando para uma 'ligação mais elástica entre sagrado e profano, mercado e religião'. Partindo dessa dinâmica e no caso específico brasileiro, é possível identificar que autores como Campos demonstram que 'existe um processo de reformulação do universo religioso, que tem seu desdobramento de forma intensa e bruta'. A necessidade desse pluralismo religioso fez com que as unidades de libertação/salvação, criassem uma disputa intensificada pelo mercado altamente competitivo, criando novas estratégias segundo a lógica de mercado, com o objetivo de produzir bens religiosos mais reais, de fácil visualização e aceitação pelos fiéis religiosos. Outra consequência dessa reformulação do ambiente de fé brasileiro é a velocidade do trânsito religioso que, por sua vez, está diretamente relacionado com processos de mudança social, como 'migrações, aumento da população urbana, crises econômicas e congêneres'. A partir deste panorama religioso percebe-se que a lógica de mercado predomina entre as empresas/igrejas, em que a negociação de bens simbólicos e o aperfeiçoamento dos 'gestores religiosos' que determinam novos rumos para esses empreendimentos. Segundo Bourdieu, 'existe na sociedade contemporânea uma situação de concorrência na área de manipulação simbólica do ambiente privado da vida das pessoas por inúmeros agentes: clérigos, membros de seitas e outros'. Com essa nova realidade social, é possível perceber o surgimento de novas correntes como plataforma de imersão ao movimento neopentecostal, evidenciando um 'processo de ruptura de sua matriz pentecostal tradicional', e sua raiz histórica protestante; faz-se necessário um recorte histórico/econômico, que foi realizado para melhor aferir as características mercadológicas de expansão existentes, percebeu-se que este movimento religioso foi um dos que apresentou maior crescimento monetário nas últimas décadas. ${ }^{65}$

A teologia da prosperidade, sem lugar à dúvida, desfruta de grande audiência no meio evangélico brasileiro, desde que frente a uma realidade socioeconômica de exclusão e de incerteza. Termina por colocar no mercado da fé um capital simbólico de confiança junto ao crente, de que ele pode, amparado pela energia religiosa, transfigurar a si mesmo, mudando as suas circunstâncias. Evidentemente, as denominações evangélicas mais tradicionais permanecem

65 PONTES, J. A. et al. Neopentecostalismo: a ressignificação mercadológica do pentecostalismo tradicional. Revista Unitas, v. 5, n. 1, p. 60-61, Vitória, 2017. 
reagindo, ainda que sem grande sucesso, a essa formulação teológica, sob o argumento de que é concessivo à dimensão material, na medida em que sinaliza para um possível processo de dessacralização da fé.

$\mathrm{Na}$ temática Antropologia Neopentecostal, temos uma observação interessante a ser feita:

\begin{abstract}
E isso se tornaria possível na medida em que o fiel se disponibiliza a viver de acordo com a vontade de Deus. O desafio a ser enfrentado é o de promover a morte de tudo o que se torna expressão de fragilidade humana enquanto contradição ao que é definido como verdade de fé. O sujeito deve morrer para o pecado para renascer para uma vida nova. De acordo com Soares (2004), para que o fiel se torne um vencedor, é necessário que ele passe por uma transformação radical em sua vida. Essa transformação deve ser experimentada como um novo nascimento. Na lógica das explicações neopentecostais, esse novo nascimento é possível graças ao ajustamento do fiel às exigências da Sagrada Escritura. A lógica que aqui se instaura é a de uma relação direta entre fé e ética. O mapeamento do universo subjetivo e das relações intersubjetivas é, assim, margeado e esquadrinhado à luz das exigências bíblicas e daquilo que é considerado como verdade nas construções de sentido das lógicas explicativas neopentecostais. ${ }^{66}$
\end{abstract}

Trata-se de um processo de construção de uma nova subjetividade por meio da obediência aos preceitos mandamentais de natureza ética, capazes de produzirem o homem novo, ou seja, aquele disposto a realizar uma ruptura com a vida vivida, colocando-se em um outro patamar existencial, guiado pelos valores da fé. A conexão subjacente é entre consciência e atitudes, na medida em que, alterada a primeira, a exigência é a de que haja o cumprimento da expectativa de que a segunda passe a refletir o novo homem, disposto, simbólica e concretamente, de modo a evidenciar uma forma distinta de ser e de estar no mundo, não para ser dele, mas para transfigurá-lo, sendo já o outro de si mesmo.

As ofertas neopentecostais têm, portanto, um aspecto propositivo, que diz respeito ao seu anúncio fundamental (a oferta da salvação - prosperidade - para todos os que integram a comunidade religiosa), e um aspecto de intervenção da realidade marcada pelo mal (rituais de curas e exorcismos), que implica eliminar os entraves da salvação, que tem como principal responsável, o demônio. É na teologia do neopentecostalismo que fica evidente a transição entre conversão e oferta de mudança de comportamento em relação aos bens materiais, bem como - lugar do convertido na sociedade como representante do reino de Deus instalado na terra. Assim sendo, o indivíduo convertido, dialeticamente, é desafiado a superar as barreiras dos males sociais causados pela desordem espiritual.

\title{
5.2. CONVERSÃO
}

O processo de conversão religiosa inclui certos modos de interiorização,

66 PARAVIDINIL, João Luiz Leitão; GONÇALVEZ, Márcio Antônio. Neopentecostalismo: desamparo e condição masoquista. Revista Mal-Estar Subjetividade, v. 9, n. 4, p. 1187-1188, Fortaleza, 2009. 
ou seja, é a partir da adesão religiosa que o indivíduo se torna reflexivo e pode obter a libertação, por exemplo, do alcoolismo. Ressalta-se, ainda, que é na tensão entre liberdade e determinação que se produz a pessoa liberta no contexto de crenças evangélicas, nunca sua derrota total. Assim, na libertação ritual neopentecostal, o demônio nunca é vencido de uma vez por todas, mas sofre derrotas provisórias, uma após outra, no caso de batalhas bem sucedidas. Trata-se de um sistema religioso que objetiva, por meio de processos rituais de purificação a transformação do indivíduo.

A seguir, temos um estudo que explica a conversão em termos de uma abordagem, que diz:

O processo de conversão religiosa inclui certos modos de interiorização, ou seja, é a partir da adesão religiosa que o indivíduo se torna reflexivo e pode obter a libertação, por exemplo, do alcoolismo. Ressalta-se, ainda, que é na tensão entre liberdade e determinação que se produz a pessoa liberta no contexto de crenças evangélicas, nunca sua derrota total. Assim, na libertação ritual neopentecostal, o demônio nunca é vencido de uma vez por todas, mas sofre derrotas provisórias, uma após outra, no caso de batalhas bem sucedidas. Trata-se de um sistema religioso que objetiva, por meio de processos rituais de purificação a transformação do indivíduo. ${ }^{67}$

Antropologicamente, todo o processo socioreligioso de práticas "rituais", não passa de "modernização inovadora" dos Ritos de Passagens "ancestrais". Assim, o processo de Conversão das Igrejas Neopentecostais funciona como prática sociológica de "integração do Crente na sua Comunidade Religiosa".

As curas e o exorcismo estão relacionados entre si, sendo o exorcismo um tipo de cura radical, que elimina o pai de todos os males, das doenças inclusive. Rege essa postura o que a antropologia chamou de causalidade mágica ${ }^{68}$, ao estudar a mentalidade primitiva. $O$ que para a mentalidade lógicoracional é causa natural, para o pensamento mágico - no caso, para o neopentecostal - é um instrumento utilizado pelo demônio para fazer maldades. O antropólogo Marcel Mauss chama de "mana" a ação capaz de manipular as forças sobrenaturais e que sintetiza a mentalidade e prática da magia ${ }^{69}$.

As curas e os exorcismos podem operar no fiel o que os antropólogos chamam de eficácia simbólica, na medida em que fornece um significado para os males a que o sujeito neopentecostal está submetido. A recriação do mundo exige que se volte ao seu estado caótico para, a partir daí, recriar o mundo (cosmogonia) $)^{70}$.

O desejo que possui o bem salvífico conduz todo o processo de conversão nos enredos e interpretações e garante a continuidade dos indivíduos na comunidade religiosa, na busca incessante de ressignificação e renovação do mundo.

A espiritualidade da paixão tem característica penitencial. Ela adotou inúmeras formas penitenciais externas (sociais), para provocar a

\footnotetext{
67 Revista Brasil de Ciências Sociais, Edição 60-62. São Paulo: ANPOCS, 2006, p.123.

68 Cf. MONTEIRO, P. Magia e pensamento mágico. 2 ed., Fortaleza: Atica Editora, 1990, p. 36-39.

${ }^{69} \mathrm{Cf}$. MAUSS, M \& Humbert, H. Esboço para uma teoria geral da magia. 1 ed., São Paulo: Edições 70, 2000.

70 Cf. ELIADE, M. Mito e realidade, 8 ed., São Paulo: Perspectiva, 2019, p. 124-125.
} 
conversão interior. A penitência vem sempre ligada à conversão. As Congregações Religiosas que procuram viver essa espiritualidade, principalmente passionistas (de paixão), com suas regras e constituições, propõem um projeto de vida penitencial para que a transformação aconteça em grupo, em comunidade. Converter-se sozinho é uma tarefa insana e difícil, porque toda transformação supõe também a mudança de estruturas externas. A mudança de vida põe em movimento um processo global. ${ }^{71}$

No movimento neopentecostal, é visível a relação entre espiritualidade e paixão. Uma das características da ênfase teológica neopentecostal é o "rito de passagem", ou seja, os sacrifícios com mediações necessárias à busca pelo sagrado, bem como pelo sucesso e bem-estar social. Converter-se é também mudar o status quo da vida social. Assim, é na experiência da subjetividade da espiritualidade da paixão que o processo de conversão é dado pela via do compromisso-efetivo, resultando, por sua vez, na submissão espiritual das regras da comunidade, despertando piedade pessoal, bem como respostas externas, ou seja, gerando um tipo de testemunho público de visibilidade social de libertação.

A importância do discurso religioso sobre conversão merece a seguinte observação:

Toda a teoria sociológica, da mais clássica a mais contemporânea, está aí para nos entregar a chave da explicação dessa notória vantagem comparativa de que goza o protestantismo de modo especialíssimo: o protestantismo é, por excelência, e radicalmente, uma religião de conversão individual. Para ele, conta menos como validação da fé professada a herança religiosa ou 'linhagem na fé' do que o ingresso voluntário como 'born again' numa congregação de 'renascidos'. O que vale é a inscrição pessoal num meio só de crentes. A formulação mais radical desse princípio deu no conceito puritano da believers Church. ${ }^{72}$

Registre-se, neste particular, que, se dois tipos ideais puderem ser construídos, talvez o do catolicismo corresponda ao formato da comunidade de fé, enquanto o do protestantismo equivalha ao da salvação individual. A experiência do protestantismo neopentecostal é reveladora da trajetória dessa segunda possibilidade, ao trabalhar com a poderosa ideia de que a salvação é pessoal, muito embora o converso passe a integrar uma congregação, a qual pode alimentar a sua vontade de mudança, mas não pode, em nenhuma hipótese, substituí-lo quanto ao ato, sempre pessoal, de busca da salvação.

Os pesquisadores Denis de Freitas e Adriano Furtado Holanda, declararam:

Distingue-se o termo 'conversão' do termo 'adesão', sendo que, por
adesão compreende-se qualquer forma de participação em um
movimento religioso, sem que haja alteração sistemática do estilo de
vida. Em contrapartida, a conversão envolve mudança no sistema de
valores e visão de mundo (GOMES, 2011). O novo converso assume
novas práticas, novos costumes e novas atitudes diante da vida,

71 PEREIRA, José Carlos. Espiritualidade da Paixão. São Paulo: Arte \& Ciências, 2002, p. 165.

72 PIERUCCI, Antônio Flávio. Religião como solvente: uma aula. Rev. Novos Estudos -

CEBRAP, São Paulo, n. 75, p. 120, 2006. 
fenômeno este que representa para a vida do converso 'uma divisão de antes e depois da conversão' (ALVES, 2005, p.75). A conversão também se caracteriza por novos esquemas de significação; a conversão é 'um processo psicossocial que se caracteriza pela desestruturação de esquemas de significação, seguido pela adoção de outro, estruturalmente distinto do primeiro' (ALVES, 2005, p. 73). ${ }^{73}$

As novas formas de difusão da fé, com a recorrência às estruturas midiáticas, tem o condão de fomentar a adesão, que é o entusiasmo participativo em manifestações de conjunto, marcadas, muitas vezes, por canto, dança e transe, sem que haja mudança existencial no homem e na mulher de fé. Já a conversão, aspira a proceder a uma mudança de forma e de fundo no indivíduo, levando-o, enquanto consciência e atitudes novas, a uma alteração profunda, tanto de sua subjetividade, quanto de sua conduta na vida social, reposicionando-se enquanto forma de ser e de estar no mundo, a refletir, agora, o nascimento do homem novo.

Segundo Gabriel Banaggia, Doutor em Antropologia Social pela Universidade Federal do Rio de Janeiro, a conversão e o processo de mudança cultural podem ser entendidos sob os seguintes aspectos:

No discurso antropológico, de modo geral e num primeiro momento, a interpretação do tema 'religião' optou por circunscrevê-la dentro de um sistema cultural, movimento que fez com que a própria cultura adquirisse características tidas antes como típicas do conceito de religião (CASTRO, 2002, p. 191). Ou seja: uma 'cultura' veio a ser entendida ou como um conjunto de crenças em que os indivíduos depositariam sua fé, ou como um agregado de representações compartilhadas. Similar contaminação produtiva pode ser notada na opção de inserir discursos que tematizam a conversão religiosa nos quadros da ideia de mudança cultural. É o caso de um trabalho de Joel Robbins (2004), abalizado na antropologia de Marshall Sahlins (1985), no qual são oferecidos possíveis modelos de conversão. $\mathrm{Na}$ reelaboração que empreende, Robbins (2004, p. 10-11) apresenta três diferentes maneiras de se pensar um encontro entre duas culturas, em função das modificações que cada uma sofre ou deixa de sofrer ao longo do contato. Segundo o autor, um processo de mudança cultural pode ser visto como de: 1) assimilação, quando certos grupos, ao lidar com circunstâncias novas, adéquam-nas às categorias da cultura anterior; 2) reprodução transformativa, que atestaria um esforço para relacionar categorias antigas ao mundo contemporâneo, tendo por consequência uma transformação das relações entre as categorias tradicionais; 3) adoção, que admite ser possível adotar uma nova cultura por inteiro, abrindo mão de esforços conscientes que desejariam adequá-la a categorias tradicionais. ${ }^{74}$

A corrente do protestantismo neopentecostal, nesta tipologia ternária, com certeza, encontra-se representada na ideia de que é possível a adoção integral de uma nova cultura, realizando o home de fé, uma ruptura tanto com as categorias tradicionais, quanto com a vida já vivida. A síntese da expectativa neopentecostal se encontra representada na conjugação de duas vertentes

\footnotetext{
${ }^{73}$ FREITAS, Denis de; HOLANDA, Adriano Furtado. Conversão religiosa: buscando significados na religião. Rev. Interinst. Psicol., v. 7, n. 1, p. 93-105, Jun., 2014. ${ }^{74}$ BANAGGIA, Gabriel. Conversão: Conversão, com versões: a respeito de modelos de conversão religiosa. Rev. Religião \& Sociedade, v. 29, n. 1, p. 201, Rio de Janeiro, 2009.
} 
mutacionais: a da consciência e a das atitudes. Em um processo simbiótico, a consciência geraria novas atitudes e essas, por sua vez, retroalimentariam a consciência.

Consideremos a seguinte análise:

O termo experiência religiosa emerge de uma preocupação antiga em estudar o papel da religião em relação à cultura, que remonta do teórico holandês Gerardus Van der Leeuw (1970 apud Bello, 1998). O autor propõe compreender a experiência religiosa a partir de suas manifestações, isto é, a partir dos fenômenos vividos pelos sujeitos. Utilizando como referencial o filósofo Benjamin Constant, o autor trabalha com o conceito de sentimento religioso, que significa 'o impacto do universo sobre nós', isto é, a consciência da infinitude do universo e da finitude humana (MENDONÇA, 2004, p. 72). Podemos dizer que tal consciência torna-se ainda mais contundente em episódios de adoecimento, em que se intensificam o medo da morte e o sentimento de fragilidade diante da vida. Nesse sentido, para o autor, a fenomenologia permite compreender a relação do homem com o poder que emana da experiência religiosa. Ao viver essa relação com o sagrado, o indivíduo 'procura elevar a sua vida, aumentá-la, conquistar-Ihe um sentido mais amplo e mais profundo' (VAN DER LEEUW, 1970 apud BELLO, 1998, p. 109). ${ }^{75}$

A construção de sentido, se é o grande desafio do homem na vida do mundo, encontra na ambiência religiosa uma capacidade simbólica possante, em face do oferecimento de respostas para o seu condicionamento ao tempo e ao espaço. A brevidade da vida, frente à dimensão da eternidade e do infinito, que o código religioso contém, nele encontra uma possibilidade de repouso e de harmonia que, talvez, não se tenha quer no ambiente puramente racional de determinadas correntes filosóficas, quer nas vertentes reducionistas da verdade às provas científicas experimentais. De outra esfera, a experiência religiosa possui uma abertura singular, a um só tempo, para a imanência e a transcendência.

\subsection{TRANSFORMAÇÃO SOCIAL}

A conversão sintetiza, com o eixo "posse da transformação social do indivíduo", a lógica religiosa fundante e fundamental do neopentecostalismo: criação-queda-redenção. Eis aqui uma consideração importante:

As ciências sociais veem a comunidade como uma força conservadora que resiste às mudanças. Por exemplo, um pastor ressente-se da pressão de seus colegas de sacerdócio que instam com ele para que não se apresse para implementar um programa de liderança eficaz na paróquia. As conexões entre a comunidade e a mudança pessoal são fortes. As tradições religiosas reconhecem que a fé tem dimensões comunitárias. Embora a conversão religiosa implique a transformação pessoal, raramente isso se dá de modo isolado. Para que a conversão amadureça e se torne uma nova forma de vida, os crentes devem

\footnotetext{
${ }^{75}$ MOTAL, C. S.; TRADI, L. A. B.; BOASLL, M. J. V. B. V. O papel da experiência religiosa no
} enfrentamento de aflições e problemas de saúde. Rev. Interface: Comunicação, Saúde, Educação, v. 16, n. 42, p. 667, Botucatu, 2012. 
tornar-se parte de uma comunidade que crê. Sua fé, nova e frágil, é alimentada com esses outros crentes, por exemplo, o rito de iniciação dos adultos entre os católicos é testemunho dessa convicção. Se os laços entre a comunidade e a transformação pessoal são fortes, também são fortes os laços entre a comunidade e a reforma social. ${ }^{76}$

Portanto, o Homem (Espírito e Matéria; Mente e Corpo) é uma Totalidade, impossível de ser reduzido a uma única dimensão linear. Assim, é impossível biológica, antropológica, sociológica, filosófica e teologicamente se propor uma TRANSFORMAÇÃO individual ou coletiva que não contemple uma INTEGRAÇÃO INDIVIDUAL-SOCIAL, isto é, Psicologia + Sociologia: Toda Conversão Individual-subjetiva exige uma estrutura-contexto sócio-histórica.

Fica evidente teoricamente que, a Cosmovisão (Weltaschaunng) ${ }^{7778}$ das Comunidades (sistema tradicionalista e conservador de crenças, valores, costumes e práticas) é sobremaneira, contraditório com os valores "tensionais" das estruturas sociais globais (mudanças de "longo prazo"). Ora, no quesito criaçãolinovação, se respeitada a concepção da Sociologia Norte-americana Clássica, o Grupo, o Coletivo NÃO sente, NÃO pensa, NEM age; somente o Indivíduo sente, pensa e age. Porém, sem a existência de uma Sociedade devidamente integrada à uma CULTURA, é impossível a CriaçãolInovação (mudança social)! Portanto, toda criação dos Sujeitos somente é possível dentro de uma matriz contextual Cultural. Somente a Cultura está capacitada, com o seus insumos, a fornecer suportes matriciais para a criaçãolinovação dos indivíduos.

São inúmeros os depoimentos apresentados por fiéis que afirmam ter participado de algum dos eventos promovidos pela Igreja, obtendo dessa participação um retorno pessoal, na maioria das vezes, pecuniário ou negocial. Aliás, sucesso nos negócios e na vida financeira são parte habitual do discurso virtuoso/vitorioso dos membros do culto, cuja base está assentada na Teologia da Prosperidade. Suportados nas constantes campanhas e nas performances cada vez mais elaboradas de pastores e fiéis à frente das câmeras e de púlpitos, cada vez mais virtualizados. A universal segue em uma sanha dominadora, com intuito de controlar o mercado religioso, tanto no âmbito nacional, quanto no internacional. ${ }^{79}$

Agressiva recorrência ao testemunho dos abençoados que, por suposto, em razão da fé prosperaram, constitui uma forma midiática de locução direta com a consciência social, no intuito de deslocá-la e arrepanhá-la como legião integrante das hostes neopentecostais. Essa é a metodologia trabalhada pela Igreja Universal do Reino de Deus, em particular, que terminou por oferecer um padrão de comportamento institucional para as demais igrejas neopentecostais no Brasil.

\footnotetext{
${ }^{76}$ WHITEHEAD, E. Evelyn; WHITEHEAD, D. James. Comunidade de Fé: Como ser Cristãos neste Fim de Século. São Paulo: Ed. Loyola., 1995, p. 85-96.

77 Weltanschauung. (Al.: visão de mundo, cosmovisão) 1. Concepção global, de caráter intuitivo e pré-teórico, que um indivíduo ou uma comunidade formam de sua época, de seu mundo, e da vida em geral. 2. Forma de considerar o mundo em seu sentido mais geral, pressuposta por uma teoria ou por uma escola de pensamento, artística ou política.

78 JAPIASSU, Hilton; MARCONDES, Danilo. Dicionário Básico de Filosofia. 3.ed., Rio de Janeiro: Zahar, 1996, p.275.

${ }^{79}$ BENEDITO, Júlio Cezar. Religiões e religiosidades populares: o conflito religioso e a simbiose de ritos e performances entre neopentecostais e afro-brasileiros. Rev. Universitas Humanística, n. 61, p. 251, Bogotá, 2006.
} 
Este relato de Rodrigo Carlos da Rocha, do Programa de Educação Tutorial em Ciências Sociais - UERN, diz respeito à conversão e transformação social, apesar de possuir uma narrativa interessante em relação ao nosso projeto de pesquisa.

Fruto de pesquisa em andamento, o autor aborda algumas das interfaces existentes entre o pentecostalismo (ou o neopentecostalismo, de modo mais específico), de um lado e, de outro, a política e a cidadania. A Favela da Via se localiza na zona oeste de Mossoró, Rio Grande do Norte.

Os fiéis que passam a se socializar nessa rede mais ampla podem mais facilmente vislumbrar projetos, os quais antes eram vistos como irreais. É lógico que isso não é fruto só da natureza da sociabilidade do MLC. As próprias narrativas do pentecostalismo desta instituição fornecem novas referências para o fiel, que não raro passará a conceber-se como capaz de levar uma existência menos sofrida, dado que 'é filho de Deus'. Neste ponto reconheço a primeira ligação com a questão da cidadania. O fiel que não se via enquanto sujeito de direitos, antes da conversão, passará a ver-se como sujeito de direitos emanados da filiação divina. Ele torna-se cidadão; não de um mundo terreno, ou de uma nação, mas de um mundo transcendental. Com a conversão e a socialização no ambiente assentado numa cosmovisão neopentecostal ele se torna cidadão do além-mundo. Isto lhe garante margem para alçar sonhos e novos projetos, os quais são alimentados tanto pela sua condição de cidadão do além-mundo quanto pela vivência interclasses possibilitada pelo caráter da sociabilidade neopentecostal do MLC. ${ }^{80}$

É a passagem do abandono e da exclusão para o pertencimento e a inclusão. Aquele que estava à margem, por meio da fé permissiva do parto do homem novo, pode caminhar para o centro, reconhecendo a si mesmo como integrante de uma cidadania organizada como força simbólica e existencial. Cidadão do além-mundo, sim, mas dotado de uma energia renovadora, que permite, pela fé, a si e a outrem, buscar caminhos de reposicionamentos verticais na vida do mundo, possíveis a todos e quaisquer filhos de Deus. Os testemunhos de mudança alimentam a capacidade decisória dos que almejam, pela fé, retemperar itinerários de consciência e de atitudes na vida do mundo, enquanto não apenas conversos, mas conversos renascidos para a vitória.

O papel das igrejas frente às iniquidades sociais:

Alguns trabalhos se dedicam a analisar o papel de igrejas em territórios de grande iniquidade social, onde mudanças (sejam elas de ordem econômica, política ou cultural) ou a falta de investimentos públicos deixam certas populações mais expostas à violência. Em geral, é para essas populações que costumam se dirigir as ações ditas de proteção por parte de instituições religiosas. Tais ações, frequentemente, podem reforçar a conformação de guetos e sinalizam a força das organizações religiosas em promover coesão social e ajuda humanitária. Muitas iniciativas, porém, em especial no que tange à segurança e à justiça, deixam expostas a ausência ou a fragilidade do Estado em prover cuidados à população. Nesses ambientes, frequentemente, as igrejas ou os templos religiosos são tidos como lugares de refúgio, locais sagrados que oferecem proteção aos seus membros. Eles podem

${ }^{80}$ ROCHA, Rodrigo Carlos da. Redes de sociabilidades neopentecostais: interfaces com a política e a cidadania. Disponível em: <https://cchla.ufrn.br/shXVII/Anais/GT24/24.5.pdf>.

Acesso em: 05 mar. 2020. 
abrigar ou favorecer ações que visam a aumentar a autodeterminação da população para lutar contra as desigualdades sociais que a oprimem. ${ }^{81}$

A ausência do Estado no tocante à formulação e à efetivação de políticas públicas, dia a dia aumenta a dívida social no Brasil, aprofundando o abandono e as exclusões de brasileiros quanto ao compartilhamento civilizatório da qualidade de vida. Como não há vazio na vida social, as igrejas neopentecostais têm realizado a ocupação deste espaço, como entidades privadas com papel público, buscando, por meio do serviço missionário, indicar o caminho da verticalidade para as populações marginalizadas. Trata-se de uma contribuição para a emergência da cidadania, descumprida, muitas vezes, pelo Estado, que torna as igrejas agentes, quer de estabilidade social, estancando razoavelmente revoltas e violências, quer de mudança social, ao oferecer a conversão como forma de transfiguração pessoal com repercussão comunitária.

Um dos projetos mais fascinantes no Brasil sobre conversão como processo de transformação social de indivíduos desassistidos pelo Estado tem sido o do CADI - Centro de Assistência e Desenvolvimento Integral. O projeto apresenta os seguintes princípios norteadores para a transformação de comunidades pelo evangelho integral:

1. Há uma mutualidade no servir. No crescimento pessoal e comunitário, tanto o que 'ajuda' como o que é 'ajudado' têm a sua parcela de contribuição. 2. O desenvolvimento está para a assistência comunitária, assim como o discipulado está para a evangelização pessoal. O desenvolvimento foi exposto como um discipulado em nível comunitário. 3. Estratégias mudam de lugar para lugar, mas existem, para qualquer contexto, princípios norteadores comuns do desenvolvimento comunitário. É importante o trabalho preventivo por meio de uma atuação direta nas comunidades, onde se originam os problemas sociais. 4. A geração de líderes locais capacitados, que servirão de multiplicadores, deve ser o propósito do trabalho comunitário. Por último, ver pessoas transformadas e como o instrumento de luta contra todas as dificuldades que certamente encontramos no trabalho de transformação comunitária. ${ }^{82}$

O CADI - Centro de Assistência e Desenvolvimento Integral é uma organização cristã, sem fins lucrativos, que visa prestar assistência, desenvolver e facilitar a transformação de comunidades carentes, numa perspectiva bíblica e lado a lado com a comunidade local. Por isso, o CADI atua em diversas áreas, de acordo com as necessidades e o potencial da comunidade, desenvolvendo projetos na área de educação infantil, escolinha de futebol, informática, ensino profissionalizante, saúde, alfabetização de adultos, cultura etc.

Assim sendo, o neopentecostalismo, por sua vez, compreende no seu itinerário a conversão como processo de transformação social, atuando nas esferas da vida de pessoas e comunidades tão necessitadas de ações sociais, capazes de revolucionar a consciência e as atitudes de vontade das pessoas.

${ }^{81}$ RIBEIRO, Fernanda Mendes Lages; MINAYO, Maria Cecília de Souza. O papel da religião na promoção da saúde, na prevenção da violência e na reabilitação de pessoas envolvidas com a criminalidade. Rev. Ciência \& Saúde Coletiva, v. 19 n. 6, p. 1785, Rio de janeiro, 2014. 82 CUNHA, Mauricio J. C; WOOD, Beth A. O Reino entre nós. Viçosa: Ultimato, p.15-15, 2000. 


\section{A PESQUISA EMPÍRICA}

\subsection{PARTICIPANTES DA PESQUISA}

A pesquisa foi constituída através de entrevistas individuais, entre fevereiro e junho de 2019, empregando-se questionários de pesquisa (multipla escolha) com formato de DSC. Dela participou um grupo de 12 pessoas de ambos os sexos, na faixa etária de 18 a 75 anos, de classe média, com a peculiaridade de que todos eram participantes da Comunidade de Águas ClarasDF, quando foram estimulados a refletir sobre suas experiências de conversão, segundo quatro eixos fundamentáis: fé; comunhão com Deus; mudança de vida; e participação em comunidade religiosa, como resultado de profundas mudanças espirituais, emocionais, sociais e de sentido existencial.

A pesquisa teve por base também a realização de uma consulta bibliográfica. Esta permitiu que se fundamentar-se um estudo teórico inicial de referência, que auxiliaria na determinação das variáveis e elaboração do plano geral da pesquisa. Por fim, antes que se realizar-se a coleta de dados através de entrevistas/questionários de pesquisa foi preciso estabelecer tanto as técnicas de registro desses dados como as técnicas que seriam utilizadas em sua análise posterior.

É relevante registrar que os questionários de pesquisa foram traduzidos em linguagem comum, isto é, as questões referentes à pesquisa que se propôs fazer duarante o processo de coleta de dados para análise e conclusão do presente trabalho, foram vertidas para o nível prosaico do falar cotidiano, permitindo aos entrevistados a mais direta compreensão possível, tanto do sentido do que se desejava perguntar, quanto do que se pretendia que fosse respondido, conectando os dois pólos dialógicos em questão.

As pesquntas foram feitas e as respostas devidamente registradas, todas com a permissão dos entrevistados, apenas coletando os dados, bem como consistindo de perguntas determinadas (multipla escolha), sem alteração do teor ou da ordem das perguntas, a fim de que pudessemos comparar as diferenças entre as respostas dos vários entevistados.

\subsection{LOCAL}

A pesquisa foi realizada na Comunidade de Águas Claras, na Chácara 22, Lote 01, Colônia Agricola de Águas Claras, Águas Claras-DF, Brasil. Trata-se de uma organização religiosa sem fins lucrativos, fundada em 03 de março de 1990.

A referida instituição atende pessoas carentes de assistencia espiritual e social, de ambos os sexos, com idades variadas, a partir dos 18 anos. Ela oferece aos seus fiéis atividades como: catequese bíblica, oração, reunião de libertação e cura interior, arte-terapia, atividades de educação física, palestras educativas, artesanato, alfabetização e passeios turísticos na Capital Federal.

Entre os objetivos da Comunidade de Águas Claras, com efeito, destacam-se os de promover a ressocialização dos irmãos, a manutenção de aspectos cognitivos, emocionais e espirituais, através de metodologias de 
catequese e de apoio social em oficinas diversas e, principalmente, objetivando a conversão no processo de transformação social, que é a adesão do indivíduo, voluntariamente.

De acordo com o Presidente, Reverendo Valmir Leite, a instituição atende, na atualidade, pessoas que procuram o ministério voluntariamente, visando o processo de transformação social por meio da conversão religiosa, assistida por suas atividades pastoriais. Portanto, cerca de 180 pessoas frequentam suas reuniões religiosas, contando com pastorais sociais que fortalecem a ação de conversão e de trasnformação social. Entre mulheres e homens, a Comunidade de Águas Claras conta, em média, com 100 pessoas, que são atendidas pelos chamados ministérios de eficiencia espritual e social. O projeto é chamado de Criação de Deus e seu horário de funcionamento é integral, pois a entidade fica aberta por 24 horas ao público.

Neste projeto participaram 12 pessoas, integrantes da Comunidade de Águas Claras, as quais tiveram suas vidas impactadas pelas ações religiosas, socioeducativas desenvolvidas pelo núcleo da Criação de Deus, que é um departamento da Comunidade de Águas Claras.

Vantagens da pesquisa e da paricipação de 12 pessoas: 1. Por sua flexibilidade, permitiu-se maior sinceridade de expressão, adequação para obter informações de indivíduos mais complexos e emotivos da comunidade, ou para comprovar os sentimentos subjacentes a uma opinição sobre conversão e transformação social através dos testemunhos coletados. 2, As pessoas que participaram foram designadas em razão dos testemunhos já conferidos dentro da própria comunidade. 3 . Foram importantes a observação e registro sobre testemunho, comportamento social, e atitudes de valorização humana, bem como com o bem-estar social de cada entrevistado através de um questionário de pesquisa de 04 (quatro) perguntas, sendo cada uma com 04 (quatro) opções de mutipla escolha.

\subsection{INSTRUMENTOS}

Os instrumentos desta pesquisa contiveram 04 (quatro) perguntas motivadoras, com 04 (quatro) opções de multipla escolha aplicadas em uma denominação religiosa, qual seja, a Comunidade de Águas Claras, tendo como objetivo buscar contato com a subjetividade de cada sujeito, da forma abrangente possivel. Os Instrumentos foram utilizados como estímulo para provocar o estudo, mantendo o foco de luz na temática proposta. Eis as Perguntas Motivadoras:

1. Como você definiria conversão (qual é o seu conceito de pertencer a uma comunidade religiosa, ou seja, de aceitar a fé como sentido existencial)?

2. Como você definiria transformação social (qual é a sua percepção de se tornar um cristão convertido no contexto social, isto é, qual é o seu impacto na vida cotidiana)?

3.Para você, o que, na conversão, mais contribuiu para sua transformação social (considerando a sua prática religiosa, quais são o sentido, o significado e a utilidade que atribui ao fato de ter se convertido)?

4. Qual é a relação que você percebe entre conversão e trasnformação social (como você explica essa ideia de ser um cristão convertido e o seu reflexo 
nas relações sociais, tais como as da igreja, da família, do trabalho, do sentimento, da emoção e da perspectiva de futuro)? escolha.

Para cada pergunta foi oferecido quatro 04 (quatro) opções de múltipla

\subsection{PROCEDIMENTO}

Os entrevistados do questionário de pesquisa se reuniram durante umas três horas, sempre de uma segunda-feira, de fevereiro a junho de 2019, às 14 h00min, momento em que acontece o ministério de estudo bíblico coletivo. $\mathrm{O}$ tempo de entrevistas não significa que tivemos apenas esta carga horária. $\mathrm{Na}$ verdade, desde janeiro de 2018, temos acompanhando a referida comunidade, buscando coleta de dados, bem como todas as informações possíveis sobre o trabalho de conversão e transformação social, por ela desenvolvidos.

Após a apresentação nominal do pesquisador, da Universidade onde o projeto de pesquisa será apresentado, foram feitos os esclarecimentos sobre os objetivos e os procedimentos da entrevista, com a leitura do Termo de Consentimento Livre e Esclarecido aos participantes. Depois de encerradas todas as dúvidas dos entrevistados, foi solicitada a assinatura por parte de cada sujeito, iniciando-se, assim, a formação do grupo para aplicação do instrumento.

As 04 (quatro) perguntas formuladas do questionário de pesquisa, sendo cada uma de multipla escolha (04 opções em cada pergunta), foram aplicadas por um mediador e um observador auxiliar, na sequência pré-estabelecida, de forma oral. Desta maneira, quando cada pergunta foi anunciada, houve a solicitação a cada participante, de que emitisse a sua opinião, permitindo que todos os sujeitos podessem se expressar.

A entrevista foi redigida em papel formato A4, por meio de formulários e todos os entrevistados teveram oportunidade de expressar sua resposta sobre cada pergunta, de forma simples e objetiva, sentindo-se mais a vontade, cabendo ao mediador somente intervir de maneira cortez, em ocasiões em que o (s) entrevistado (s) se desviasse $(\mathrm{m})$ da temática proposta. Foi esta técnica, baeada no DSC, que se permitiu a análise de dados quantificáveis.

\subsection{ANÁLISE DOS DADOS}

A coleta de dados (pesquisa bibliográfica, documentação em geral, observação, entrevista e questionário de pesquisa) é a fase da pesquisa que tem por objetivo obter informações sobre a realidade. Conforme as informações necessárias existem diversos instrumentos e formas de operá-los. Esta foi a metodologia da pesquisa: sujeitos de pesquisa, coleta dos dados e análise dos dados. Nos semelhantes estudos, a entrevista e o questionário de pesquisa são os mais frequentes instrumentos para coleta de dados. As suas respostas dão ao pesquisador a informação necessária para o desenvolvimento do estudo. "O conhecimento assim obtido refere-se à expressão verbal do fato, pelo entrevistado, sendo que na maioria das vezes, o pesquisador não observou os acontecimentos diretamente" (DENCKER, 1998, p. 137). 
As entrevistas registradas em formulários seguiram para o processo de tabulação, obedecendo ao roteiro metodológico para obtenção do Discurso do Sujeito Coletivo-DSC:

1. As questões foram analisadas isoladamente. O conteúdo de cada resposta foi copiado de forma integral, permitindo a abordagem da questão 1 de cada sujeito, e assim, sucessivamente.

2. Foram identificadas e sublinhadas as expressões-chave da ideia central em cada resposta, e quando se tornou possível, foi realizada a demarcação das ancoragens conforme as descrições apresentadas.

3. Foram identificadas as ideias centrais e possíveis ancoragens, permitindo que elas fossem colocadas em identificações correspondentes.

4. Foram identificadas e agrupadas as ideias centrais e as ancoragens de mesmo sentido, ou equivalentes, ou complementares, levando a que estes grupamentos fosem etiquetados com os números 1, 2, 3 e 4.

5. Foi atribuída a cada grupamento especificado no item 4 uma ideia central, ancoragem ou síntese, com o objetivo de expressar, da melhor forma possível, todas as ideias centrais e as ancoragens de mesmo sentido.

6. O Discurso do Sujeito Coletivo-DSC foi construído para cada participante entevistado através de um questionário de pesquisa com questões de multipla escolha, especificamente.

\section{RESULTADOS E DISCUSSÃO (A ESCOLHA DOS SUJEITOS DE PESQUISA)}

O resultado dos depoimentos ora é apresentado como Discurso do Sujeito Coletivo-DSC, entre jovens e idosos do Distrito Federal, com média entre 18 a 75 anos, sobre a conversão e transformação social do sujeito coletivo, no contexto do estudo de um estudo do neopentecostalismo brasileiro.

Foram realizados todos os passos da metodologia proposta, sendo que cada um de todos os 12 participantes da pesquisa, oriundos da Comunidade de Águas Claras-DF, caracterizou o interesse coletivo. Ao final do trabalho de campo foi aplicado um questionário de pesquisa (avaliação) para coleta de dados com quatro perguntas, sendo que cada pergunta teve quatro opções de multipla escolha, às quais os participantes responderam por escrito e sem identificação. Os entrevistados receberam instruções sobre como participar do questionário de pesquisa (avaliação), entender a linguagem de cada questão (1.2.3.4.), bem como de sua multipla escolha (A.B.C.D). A amostra foi organizada com $100 \%$ dos 12 entrevistados, totalizando 12 questionários individuais, obviamente, com 48 questões alternativas no geral. O IAD (Instrumento de Análise de Discurso), o DSC (Discurso do Sujeito Coletivo) da Tabela 1, bem como Síntese do DSC por Tópico da Tabela 2 representam, neste caso, a formatação geral da representação da estrutura técnica da pesquisa.

Serão apresentados resultados quali-quantitativos, sem os resultados qualitativos apresentados sob a forma de DSCs, e os quantitativos sob a forma de gráfico.

Resultados qualitativos

Ideias Centrais

a. O projeto da Comunidade de Águas Claras possibilita o trabalho como 
significativo e incentivando a conversão e as atividades sociais entre os seus participantes.

b. O projeto da Comunidade de Águas Claras estimula a conversão através de uma estratégia social especifica que favorece o processo de inclusão e a transformação do indivíduo na vida social.

c. O projeto da Comunidade de Águas Claras possibilita comunhão religiosa, resgate de valores humanos e sociais dos indivíduos.

d. O projeto da Comunidade de Águas Claras contribui para restaurar vidas, proporcionar novos direcionamentos existenciais e sociais, além de reintegrar à sociedade indivíduos com um novo formato de psicossocial.

A Tabela 1 descreve O Discurso do Sujeito Coletivo-DSC, que é o resultado do pensamento dos Sujeitos sobre cada um dos quatro Instrumentos de Análise do Discurso (IAD).

Tabela 1 - (DSC) por (IAD)

1) Como você
$\begin{aligned} & \text { IAD } \\ & \text { definiria conversão (qual }\end{aligned}$ $\begin{aligned} & \text { Disseram: Mudança de caráter; } \\ & \text { transformação espiritual e social; mudança de } \\ & \text { é ostumes e hábitos; compromisso com Deus; } \\ & \text { pertencer a conceito de } \\ & \begin{array}{l}\text { comunidade religiosa, } \\ \text { ou seja, de aceitar a fé }\end{array}\end{aligned}$


4) Qual a relação que você percebe entre conversão trasnformação social (como você explica essa ideia de ser um cristão convertido e o seu reflexo nas relações sociais, tais como igreja, família, trabalho sentimento, emoção e perspectiva de furuto)?
Disseram: Confiança e oportunidade de novos vinculos; ajudar outras pessoas que vivem em risco social; comunhão com Deus, familia e pessoas proximas; valores redefinidos à luz de Deus; harmonia entre o espiritual e 0 social; transformação integral:religiosa e social; completude humana; a fé foi a ponte para o social positivo; o social é o reflexo do espiritual; a mudança religiosa foi capaz de trazer novas perspectivas de valores antes não vistos.

A Tabela 2 descreve os tópicos mais relevantes, em um quadro-síntese, com as ideias centrais do Discurso do Sujeito Coletivo-DSC, como representativos do processo de inicialização da conversão, até o processo de transformação social vivênciado pelos Sujeitos:

Tabela 2 - Síntese do (DSC) por Tópico

\begin{tabular}{|c|c|}
\hline Principais Tópicos & Discurso do Sujeito Coletivo \\
\hline $\begin{array}{ccc}1 . & \text { Tempo } & \text { de } \\
\text { conversão religiosa. }\end{array}$ & $\begin{array}{l}\text { A conversão é um processo continuo. É } \\
\text { necessário total dedicação espiritual e } \\
\text { envolvimento com a proposta do evangelho de } \\
\text { Deus. O resultado é a mudança de paradigma } \\
\text { religioso-social. No minimo, nove meses para } \\
\text { perceber o processo de conversão. }\end{array}$ \\
\hline $\begin{array}{l}2 . \quad \text { Início de } \\
\text { relacionamento com a } \\
\text { comunidade. }\end{array}$ & $\begin{array}{l}\text { Por intermédio de amigos da família, } \\
\text { evangelizadores e amigos. }\end{array}$ \\
\hline $\begin{array}{l}3 . \quad \text { Nível de } \\
\text { estabelecimento de } \\
\text { laços de comunhão } \\
\text { através das atividades } \\
\text { da comunidade. }\end{array}$ & $\begin{array}{l}\text { Formal ou informal, dependendo da } \\
\text { conversão de cada fiel da comunidade. Os } \\
\text { serviços da comunidade ajudam no processo } \\
\text { de transformação espiritual e engajamento } \\
\text { social. }\end{array}$ \\
\hline $\begin{array}{l}\text { 4. Ministérios de } \\
\text { crescimento pessoal e } \\
\text { coletivo antes e depois } \\
\text { de decidir pertencer a } \\
\text { cmunidade. }\end{array}$ & $\begin{array}{l}\text { Aumento no ciclo de amizades. A família } \\
\text { e as pessoas próximas percebem mudanças } \\
\text { significativas à patir do entrosamento } \\
\text { religioso. A comunidade é a base para o } \\
\text { testemunho público da conversão. }\end{array}$ \\
\hline
\end{tabular}

Resultados quantitativos DSCs.

O gráfico abaixo representa a frequência relativa dos diferentes tipos de

Como se processa a dialética conversão e transformação social? 


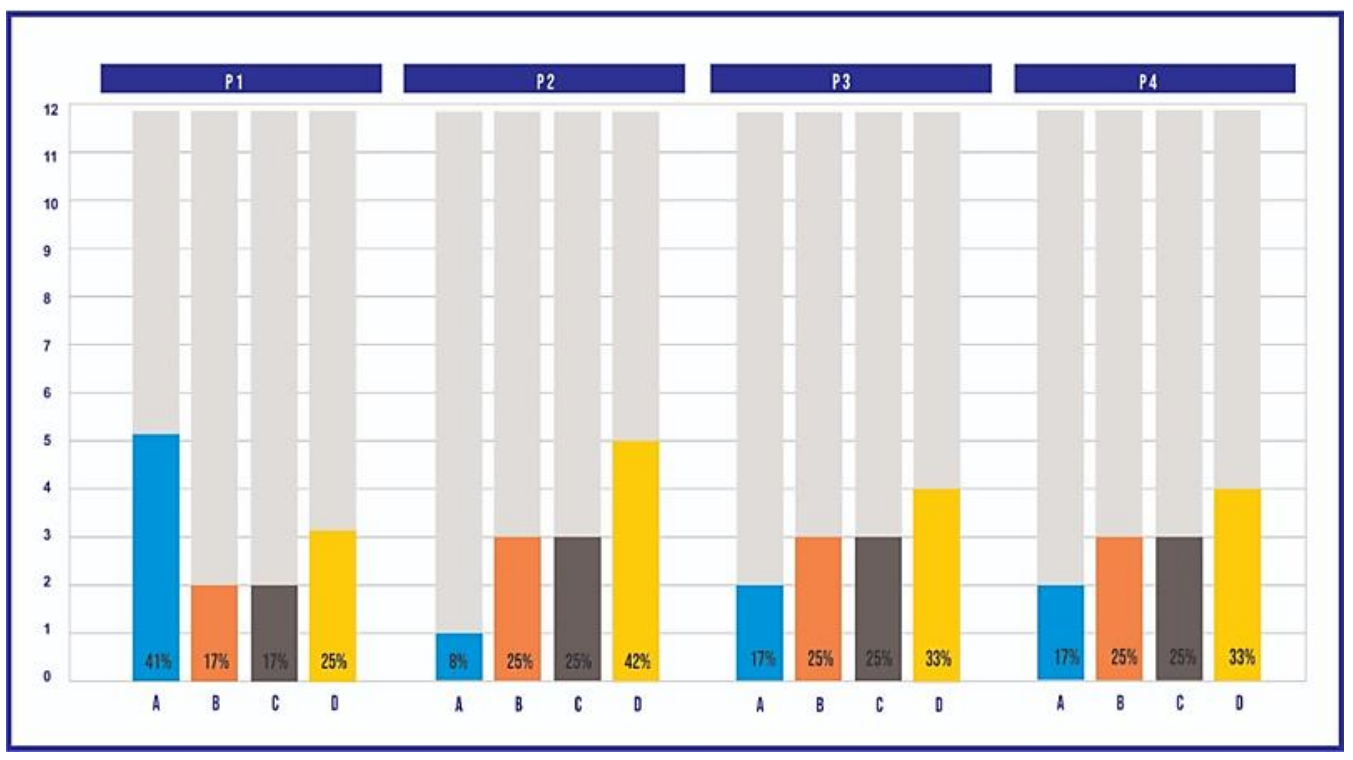

Quando tratamos de dados quantitativos nos quadro do DSCs, é preciso que fique claro o que está sendo objeto de quantificação.

Conforme a metodologia do DSC, as Ideias Centrais dizem respeito ao que poderíamos chamar de nome do sentido do discurso professado por cada um dos sujeitos entrevistados.

DSC 1. A comunidade estimula a conversão e o comprometimento com todos os seus ideais.

DSC 2. A comunidade contribui com evangelismo afetivo e interativo

DSC 3. A comunidade possibilita o discipulado, a comunhão mútua e as atividades socioeducativas.

DSC 4. A comunidade tem como missão promover o testemunho interno (religioso) e externo (social) de todos os seus integrantes.

Em um trabalho sobre o DSC foi colocado que ele expressa uma Soma Qualitativa (Lefèvre \% Lefèvre, 2003) na medida em que cada depoimento de cada entrevistado faz parte de um determinado discurso coletivo que reúne em si depoimentos de sentidos semelhantes ou complementares.

A quantidade, portanto, diz respeito ao número ou percentual de pessoas, ou, mais precisamente, de repostas, que contribuíram, com sua parte, para a construção de um discurso entendido como um desdobramento de uma ideia, em seus conteúdos e argumentos correspondentes.

Os dados quantitativos não se referem, em consequência, à frequência das Ideias Centrais, mas, mais precisamente, à frequência de respostas que contribuíram para a construção de um DSC que, por comodidade, se denominou de um determinado modo. Assim sendo, encontrou-se, que, do total de respostas às perguntas aqui obtidas, contribuíram para a constituição de um DSC cuja ideia Central sinaliza para a percepção de que a Comunidade de Águas Claras foi entendida como uma instituição que, através da catequese e das atividades sociais, desenvolvidas voluntariamente, propiciou a ressocialização dos seus participantes.

Os dados quantitativos mostraram que as respostas frequentes são em relação aos DSCs, cujo sentido atua em torno da ideia de que a conversão, como 
processo de transformação social (alteração de comportamento individual e social), resulta como proposta pelo corpo dirigente institucional, sob as circunstâncias de que a comunidade, a princípio, objeto, se torna sujeito do processo em curso de sua própria mudança.

Outro ponto que merece ser destacado é quanto à frequência dos DSCs da Pergunta 1 (A 41\% B 17\% C 17\% D 25\%). Este percentual é bastante revelador, se levarmos em conta os desafios que a comunidade oferece, os quais, através da relação fé-trabalho (catequese e atividades sociais) indica cenários verticais, almejando ser parte dos novos objetivos do universo social em mudança, tendo como base o sentido de conversão. A Letra A da Pergunta $1=41 \%$, demonstrou ser a conversão religiosa um fator determiante de transformação social.

Vejamos os perceptuais nos DSCs da Pergunta 2 ( A 8\% B 25\% C 25\% D $42 \%$ ) e da Pergunta 3 (A 17\% B 25\% C 25\% D 33\%), os quais permitem concluir que a importância da conversão como processo de transformação social é imprescindível para a manutenção do projeto e seus desafios. Ficou, desta maneira, demonstrado o devenido (passado) e o devenir (presente sinalizado para o futuro) dos entrevistados em relação às pesguntas 2 e 3.

A Letra $D$ da Pergunta $2=42 \%$, demonstrou que a relação entre conversão e transformação social, contribuiram substancialmente. A Letra D da Pergunta $3=33 \% \%$, demonstrou que 0 engajamento social favoreceu significativamente o objetivo proposto.

Devem também ser levadas em consideração as frequências do DSC da Pergunta 4 (A 17\% B 25\% 25\% D 33\%) , que é relativo a aspectos positivos de novas experiências, conquistas, autoestima, desenvolvimento das habilidades humanas e ressocializações.

A Letra D da Pergunta $4=33 \%$, demonstrou a certeza de ressignificação de valores e vinculos humanos e sociais, sendo relevantes para o processo de transformação social.

Finalmente, deve-se destacar que a metodologia de análise qualiquantitativa (Lefèvre \% Lefèvre, 2003) proposta, mostrou-se um instrumento valioso para a geração de dados indicados, os quais, na dialética conversão e transformação social a partir do estudo da Comunidade de Águas Claras-DF, viés do neopentecostalismo brasileiro, podem ser significativos, tanto para as comunidades do movimento neopentecostal, quanto para os estudiosos do fenômeno religioso em geral, por indicarem, de um ponto de vista da experiência da comunidade em estudo, que a fé é uma força movente e transformadora da vida, quer pessoal, quer social.

A conversão ao processo de transformação social resultante na vida cotidiana de cada entrevistado possui o seguinte perfil de efeitos: testemunhos de fé; práticas religiosas; espiritualidades, autoestima e seu reflexo nas relações sociais diárias; fortalecimento dos laços familiares; e, registre-se: valorização da vida. Estas são as características observadas nos resultados apresentados, inferindo-se um estabelecimento de vínculo religioso-concreto (ou seja, espiritual e social) como, observado no Discurso de Sujeito Coletivo-DSC, que proporciona ao convertido uma experiência inclusiva, diferenciada do que pensa o senso comum sobre a ineficácia de novas oportunidades sociais e tranformadoras, decorrentes da conversão religiosa significativa.

O testemunho de cada entrevistado fundamentou e solidificou a pesquisa com tanta intensidade para os convertidos, permitindo vislumbrar que acontece 
uma mudança radical, capaz de alterar pespectivas e sentidos existenciais, garantindo para o convertido à fé cristã uma qualidade de vida poderosamente impactada e impactante.

O que, positivamente, justifica uma maior atenção para com a conversão é a participação em uma comunidade religiosa, neste caso, a neopentecostal, podendo acontecer com pessoas inseridas em famílias seguras ou pessoas dessasistidas pelo Estado, pois proporciona ao convertido, ou seja, à pessoa inserida no contexto do acolhimento religioso, uma maior segurança a respeito das suas buscas espirituais e existenciais, e também, pela necessidade frequente com que estes convertidos são envolvidos, por exemplo, no trabalho de evangelização terapêutica e transformação social relevante.

Os resultados demonstraram que nenhum dos entrevistados teve intenção de abandonar a proposta de conversão integral: espiritual e social conversão e transformação social -, de acordo com os relatos de experiências de discipulado e libertação que ocorreram de forma individual e também coletiva, considerando os aspectos do discupulado religioso e ambientais de cada sujeito.

O processo de transformação social ocorreu através de catequese, oração diária, leitura da Bíblia, busca pelo propósito da existencia dada por Deus, independemente dos grandes desafios que foram enfrentados por cada um, duarante seu discipulado de libertação, com objetividade pela busca do sentido existencial e social do sujeito, enquanto imagem de Deus (imago dei).

As perguntas construidas por este projeto de pesquisa revelaram, em consequência, o quanto tem sido positivo o trabalho realizado na Comunidade Evangélica de Águas Claras, com pessoas totalmente desacreditadas, às vezes, abandonadas, e até portadoras de patologias psicológicas, emocionais e sociais consideráveis.

O serviço religioso proposto pela Comunidade de Águas Claras, claramente, é uma oportunidade para a pessoa conquistar a oportunidade de desenvolver suas capacidades humanas e sociais, com o estabelecimento de novos vinculos interativos, e também, no sentido de se envolver no evangelismo social, que pode ser mediado pela participação em projetos sociais e em atividades religiosas.

Os resultados da pesquisa ora apresentados, também descrevem como relevantes o quadro-síntese, com as ideias centrais do Discurso do Sujeito Coletivo-DSC, representativo desde o processo de inicialização da conversão, até o processo de transformação social vivenciado pelos sujeitos, como indicativo de maior resultado do trabalho que é realizado, segundo este estudo, nas comunidades neopentecostais brasileiras. Demonstram, assim, a sua utilização como instrumento de transformação social e testemunham a existência de um elevado nível de mudança social, pela prática da atividade religiosa, bem como socioeducativa. A valorização da dignidade da pessoa humana transparece, enquanto verticalidade da cidadania, contribuindo para a construção de relacionamentos duráveis com outras pessoas, ou com familiares, bem como na projeção de investimento futuro de suas visões de enquadramento nos mais diversos setores da sociedade.

Outro aspecto significativo apresentado pelos sujeitos é o aumento nos níveis de autoestima. Existe uma relação entre autoimagem, autoestima e qualidade de vida. Em avaliação realizada pelo pesquisador, utilizando o questionário proposto, ficou demonstrado o nível elevado de qualidade de vida e autoestima e a influência destes aspectos na qualidade de vida dos 
convertidos.

Existe correlação negativa entre engajamentos em atividades eclesiásticas e sintomatologia espiritual, indicando que, quanto maior o número de atividades sociais praticadas pelos indivíduos, menores serão os escores de sintomatologia espiritual.

A utilização da conversão como recurso terapêutico pode ser uma das estratégias no resgate de pessoas que, por estarem à margem da sociedade, perderam, de alguma forma, sua representação social. A conversão constroi o sentido da identidade social e de cristalização elevada de status, porque é exatamente isso que o evangelismo neopentecostal assegura: salvação como processo de transformação social.

De acordo com os estudos apresentados, sugere-se a possibilidade da indicação da conversão religiosa e a utilização dos métodos de catequese da comunidade neopentecostal - como recurso terapêutico nos processos psicossociais, uma vez que foi possível relacionar esta conversão religiosa com mudanças significativas nos aspectos sociais: aumento nos níveis de socialização e autoestima, através da utilização do serviço religioso de conversão, com a participação integral nas atividades da comunidade neopentecostal pesquisada, visando à promoção da transformação social dos convertidos.

Explique-se, por oportuno, que o instrumento aplicado permitiu 0 aprofundamrnto quanto aos testemunhos das histórias pessoais vivenciadas, no sentido do existenciamismo cristão, em particular, que desde Miguel de Unamuno ${ }^{83}$ até Emanuel Mounier ${ }^{84}$, sempre comprendeu o fenômeno do existir

${ }^{83}$ Miguel de Unamuno (1864-1936), juntamente com Ortega y Gasset, Unamuno é um dos maiores filósofos e homens de letras da Espanha neste século, responsável pelo desenvolvimento do pensamento espanhol contemporâneo e pela introdução dos grandes temas da filosofia de sua época na cena espanhola. Nascido em Bilbao, estudou na Universidade de Madri e foi depois professor de grego e de filologia na Universidade de Salamanca (1891-1934), da qual foi também reitor. O pensamento de Unamuno é profundamente humanista e existencial, valorizando de modo central a experiência humana, contra o tratamento idealista do homem em abstrato. Combate neste sentido o cientificismo e o racionalismo. Destacou-se como poeta, romancista e crítico literário, sendo suas principais obras: Paz en la guerra (1897), Poesías (1907), Contra esto y aquello (1912), sua obra mais conhecida é Del sentimiento trágico de la vida (1913), Niebla (1914), La agonia del cristianismo (1931). (JAPIASSÚ, Hilton; MARCONDES, Danilo. Dicionário Básico de Filosofia. Rio de Janeiro: Zahar, 1996, p. 191).

84 O personalismo de Emmanuel Mounier (1905-1950) surgiu diante de uma condição histórica permeada por grandes desordens. Dentro do contexto de humanidade em crise, Mounier promoveu sempre a pessoa. Defendeu uma retomada dos inalienáveis direitos humanos, abriu vias para o universo ético da pessoa em seu tempo e lugar. Propôs um despertar, um desabrochar de existência verdadeiramente humana feita de imanência e transcendência. Assim, desperta a pessoa, ser-no-mundo e com-o-mundo, assume a humanidade, recusa a passividade e o conformismo diante das ameaças alienantes de qualquer natureza. Elegendo-se, compromete-se numa luta permanente para humanizar a humanidade. Sua filosofia, que une reflexão e ação, chegou às outras margens do Atlântico e teve progressivamente repercussão no Brasil a partir da década de 50. Momentos de grande produção intelectual, cultural, filosófica, política e social foram vividos como jamais vistos na História do Brasil. Tudo foi interrompido pelo Golpe Militar de 1964, o qual punha fim à primavera dos tempos de libertação, de educação e de cultura centrada na dignidade da pessoa humana. Ao furtar a lógica das estações, iniciava-se um longo período de inverno sombrio. Período que jamais pode ser esquecido, embora atualmente, tudo se faça para rejeitar este passado vergonhoso. Ainda que sob o punho de ferro da ordem totalitária (desordem estabelecida), o personalismo no Brasil, na década de 70 , conseguiu manter a centelha acessa, através de uma incoativa trincheira de um pensar mais especificamente filosófico. Com o passar do tempo, ao sintonizar os dias atuais, nota-se que 
e do existente como drama agônico a ser redimido pela fundação de uma nova esperança fundamentada na fé transfiguradora do home de carne e nervo, osso e sangue que, se uma dia morre, precedentemente tem que viver, existindo com dignidade.

\section{CONSIDERAÇÕES FINAIS}

Os resultados apresentados pela pesquisa foram obtidos e avaliados a partir, apenas, dos depoimentos dos sujeitos. Por este motivo, algumas questões apresentadas como instrumento motivador resultaram, empiricamente, como uma contribuição efetiva aos estudos da religião como fenômeno social.

Com o objetivo de trazer o entendimento sobre algumas das questões norteadoras, houve, de maneira episódica, a interferência do pesquisador, possivelmente, com risco controlado de enviesamento de algumas das respostas, para, enfim, facilitar o entendimento de terminologias usadas nas entrevistas através de questões sempre fechadas.

Sugere-se, conclusivamente, uma ampla discussão e continuada pesquisa sobre o papel que essas comunidades neopentecostais vêm realizando no Brasil, e, em particular, se possível, uma maior atenção por parte de teólogos, filósofos, historiadores, juristas, antropólogos, psicólogos e sociólogos, para o fenômeno social e religioso em questão, vencendo preconceitos cientificistas e avançando, de maneira transversal, em busca do seu substantivo conhecimento. 85

Conversão e mudança social dos sujeitos entrevistados, com certeza, podem ser estudados em profundidade, enquanto expressão do fenômeno da responsabilidade social eclesiástica, sob o signo desafiante da solidariedade.

Concomitantemente, quanto ao trabalho da Comunidade de Águas Claras, visando a obtenção do Discurso do Sujeito Coletivo, sugere-se que seja feito um recorte transversal com convertidos, em período anterior e posterior ao processo conversão e transformação social, com a aplicação de algumas escalas como de experiência mundana, mudança de crença, frequência a reuniões religiosas, discipulado, integração eclesiástica e transformação social, com ênfase subjetiva (busca pessoal) e objetiva (enquadramento na sociedade), permitindo uma avaliação mensurada e continuada do fenômeno em discussão.

A diversificação de gênero na pesquisa foi a intenção inicial, permitindo matizar o objeto, escolha que facilitou a estimulante abordagem da instituição religiosa examinada e analisada de maneira plural, vencendo preconceitos patriarcais e estabelecendo um elo com a percepção democrática da

novos episódios contra a dignidade humana ocorrem diariamente. Não é estranho pensar que, aludindo no início do século XXI ao enfoque defendido por Mounier, venha-se a redescobrir que a ideia de pessoa pode contribuir muito para o nosso tempo. O pensamento de Mounier sobre a pessoa pode fornecer subsídios para um despertar pessoal que abarque os outros, promova uma ética de responsabilidade e traga consigo, nas estruturas de seu universo pessoal, a novidade, tão necessária a uma comunidade (comum-unidade) que precisa urgentemente entender-se como planetária. (Silveira, Carlos Roberto da. $\mathbf{O}$ humanismo personalista de Emmanuel Mounier e a repercussão no Brasil. 2010. 243 f. Tese (Doutorado em Filosofia) Pontifícia Universidade Católica de São Paulo, São Paulo, 2010).

85 COMISSÃO TEOLÓGICA INTERNACIONAL. Em busca de uma ética universal: novo olhar sobre a lei natural. São Paulo, Paulinas, 2009, p. 109. 
comunidade de fé.

Outro aspecto relevante, sem dúvida, com a obtenção respondente de sujeitos de ambos os gêneros, foi o aumento de sua margem de percepção social. É de se considerar, recorde-se, que o objetivo da pesquisa foi o da utilização dos dados para evidenciar que a conversão é mediada ${ }^{86}$ pelo processo transformação social, deixando evidenciado o quanto é de considerável significado o microcosmo social pesquisado, permitindo o reconhecimento dos resultados legitimos obtidos pela presente pesquisa, despida de enviesamentos ideológicos, nos quais, por equivoco, a cegueira do espírito repúdia o espelho solar da fé enquanto força movente da transformação social.

Comprovar o valioso trabalho de pesquisa no contexto do neopentecostalismo brasileiro, ainda que moderadamente sensível problema exposto, de tentativa de transfiguração do homem na vida do mundo por meio da fé, com resultados especificos da experiencia estudada da Comunidade Águas Claras-DF, no que permite, com sua base empirica, auferir e comunicar. Trata-se de reconhecer, segundo a razao sensivel, propugnada desde JeanJacques Rousseau ${ }^{87}$ até Michel Maffesoli88, como a possível resposta adequada

${ }^{86}$ Mediação (do lat. Tardio mediatio). Na dialética hegeliana, e posteriormente na marxista, a mediação representa especificamente as relações concretas - e não meramente formais - que se estabelecem no real, e as articuçações que constituem o próprio processo dialético" (JAPIASSU, Hilton; MARCONDES, Danilo. Dicionário Básico de Filosofia. 3.ed., Rio de Janeiro: Zahar, 1996, p. 177).

${ }^{87}$ Jean-Jacques Rousseau (1712-1878). Jean-Jacques Rousseau nasceu em Genebra, Suíça, de uma família de origem francesa. Em 1742, instalou-se em Paris e vinculou-se ao movimento enciclopedista, especialmente, a Diderot, tendo uma vida mundana. Manteve um relacionamento com Thérèse Le Vasseur, com quem teve cincos filhos que entregou à assistência pública. Em 1750, publicou o Discurso sobre as ciências e as artes, rompendo com o otimismo do Século das Luzes. Em 1755, publicou o Discurso sobre a origem da desigualdade, que the deu celebridade e the causou problemas (polemizou com Voltare e outros). Em 1762, publicou o Contrato social, livro que o levou a exilar-se na Suíça, depois na Inglaterra. Finalmente, retorna à França, onde morre. Dos temas por ele abordados, destacam-se: a) o homem é, por natureza, bom, é a sociedade que o corrompe, quer dizer: a sociedade não é, por essência, corruptora, mas somente certo tipo de sociedade, isto é, aquela que repousa na afirmação da desigualdade natural dos homens, oprimindo a maioria em proveito de uma minoria privilegiada; b) o estado de natureza é um estado primordial onde o homem vive feliz, em harmonia com o mundo e na inocência, não havendo necessidade de sociedade: o social não tem sua norma na natureza, mas no homem, a passagem da natureza à sociedade é puramente contingente, é uma causalidade puramente externa que o induz a isso; c) o homem difere essencialmente dos outros seres naturais e animais por sua perfectibilidade. O problema, para ele, consiste em encontrar uma forma de sociedade na qual possa preservar sua liberdade natural e garantir sua segurança; d) para solucionar esse problema, Rousseau propõe o contrato social. O soberano é o conjunto dos membros da sociedade. Cada homem é, ao mesmo tempo, legislador e sujeito. Ele obedece à lei que ele mesmo fez. Isso pressupõe uma vontade geral distinta da soma das vontades particulares. Cada homem possui, como indivíduo, uma vontade particular, mas também possui, como cidadão, uma vontade geral da qual é membro. Cabe à educação formar essa vontade geral (JAPIASSÚ, Hilton; MARCONDES, Danilo. Dicionário Básico de Filosofia. Rio de Janeiro: Zahar, 1996, p. 238).

88 Michel Maffesoli, nascido em 14 de novembro de 1944, na cidade de Graissessac, na França. É um sociólogo conhecido sobretudo pela popularização do conceito de tribo urbana. Antigo aluno de Gilbert Durand, é professor da Université de Paris-Descartes. Michel Maffesoli construiu uma obra em torno da questão da ligação social comunitária e a prevalência do imaginário nas sociedades pós-modernas. Ele é secretário geral do Centre de recherche sur l'imaginaire e membro do comitê científico de revistas internacionais, como a Social Movement Studiese Sociologia Internationalis. Michel recebeu o Grand Prix des Sciences Humaines da Academia Francesa, em 1992, por seu trabalho La transfiguration du politique. Ele é também vicepresidente do Institut International de Sociologie (I.I.S.), fundado em 1893 por René Worms, e 
para os infinitos desafios objetivos e subjetivos do eterno enigma chamado homem.

membro do Institut universitaire de France - I.U.F. Em 2011, recebeu o doutoramento honoris causa da Universidade do Minho. (WIKIPEDIA. Michel Maffesoli. Disponível em: https://pt.wikipedia.org/wiki/Michel_Maffesoli. Acesso em: 05 de mai. 2020). 


\section{REFERÊNCIAS}

ALONSO, J. Conversión filosófica y conversión cristiana. Scripta Theologica, n. 41, 2009.

ALVES, R. O enigma da religião. Petrópolis: Vozes, 1975.

Religião e repressão. São Paulo: Loyola, 2005.

AZEVEDO, I. B. de. A celebração do indivíduo: a formação do pensamento Batista Brasileiro. Piracicaba: Unimep; São Paulo: Exodus, 1996.

BANAGGIA, Gabriel. Conversão: Conversão, com versões: a respeito de modelos de conversão religiosa. Rev. Religião \& Sociedade, v. 29, n. 1, p. 201, Rio de Janeiro, 2009.

BASTIAN, J. P. Protestantismos e modernidade latino-americana: história de uma minoria religiosa activa em América Latina. Trad. José Esteban Caldéron. México: Fundo de Cultura, 1994.

BASTOS, A. C. T. Cartas do solitário. Vol. 115. São Paulo: Nacional, 1938.

BATISTA, M. N.; CAMPOS, D. C. Metodologias de pesquisa em ciências. Análises quantitativa e qualitativa. Brasil: LTC, 2016.

BAUNGART, T. A; AMATUZZI, M. M. Experiência religiosa e crescimento pessoal: uma compreensão fenomenológica. Revista de Estudos da Religião, 2007.

BENEDITO, Júlio Cezar. Religiões e religiosidades populares: o conflito religioso e a simbiose de ritos e performances entre neopentecostais e afrobrasileiros. Rev. Universitas Humanística, n. 61, p. 251, Bogotá, 2006.

BERGER, P. O dossel sagrado: elementos para uma teoria sociológica da religião. 2. ed. São Paulo: Paulus, 1985.

Rumor de anjos: a sociedade moderna e a redescoberta do sobrenatural. Trad. Waldemar Boff. 2. ed. Petrópolis: Vozes, 1997.

BERKHOF, L. Teologia sistemática. Grand Rapids: W. B. Eerdmans, 1976.

BIRCK, B. O. O sagrado em Rudolf Otto. Porto Alegre: EDIPUCRS, 1993.

BOURDIEU, P. Os usos sociais de ciência: por uma sociologia do campo cientifico. São Paulo: Editora Unesp 2004.

Razões práticas. 4 ed., Campinas: Papirus, 1996. 
BRANDÃO, André Augusto Pereira; JORGE, Amanda Lacerda. A recente fragmentação do campo religioso no Brasil: em busca de explicações. Revista de Estudios Sociales, n. 69, p. 83-84, julio-septiembre, 2009.

BRASÍLIA. Instituto Brasileiro de Geografia e Estatística (IBGE). Censo demográfico 2010. Características gerais da população, religião e pessoas com deficiência. Rio de Janeiro: Instituto Brasileiro de Geografia e Estatística/MPOG.

BROWN, Peter. Santo Agostinho: uma biografia. 6. ed., Rio de Janeiro: Record, 2011.

CALVINI, Rocha. A responsabilidade social da igreja. Londrina-PR: Descoberta, 2003.

CALVINO, J. Institución de la religión cristiana. Trad. Cipriano de Valera. v. I e II. Rijwswijk Bajos: Fundación Editorial de Literatura Reformada, 1967.

COHEN, M. Caminhos da Bíblia. Trad. Maria da Glória A. Vaz. Rio de Janeiro: Tradição; Biblioteca de Cultura Judaica, 1967.

. Convergence: maturation and integration in the course of a religious conversion. Journal of the American Academy of Psychoanalysis, v. 30, p. 383-400, 2002.

Constituição Pastoral: Gaudium et spes sobre a igreja no mundo atual. Roma, 7 dez. 1965.

CUNHA, Mauricio J. C; WOOD, Beth A. O Reino entre nós. Viçosa: Ultimato, p.15-15, 2000.

DINIEWCS, A. M. Metodologia de pesquisa em saúde para iniciantes. São Caetano do Sul: Difusao Editora, 2007.

DOIG, K. Germán. Dicionário Rio Medellín Puebla. São Paulo: Loyola, 1992.

DURKHEIM, É. As formas elementares de vida religiosa: o sistema totêmico na Austrália. Trad. Joaquim Pereira Neto. São Paulo: Paulinas, 1989.

Classical Selections on Great Issues: Society and Solitude (Lynchburg College Symposium Readings). V. 5, University Press Of America, 1997.

. Educação e sociologia. Lisboa: Edições 70, 2001.

ELIAS, N. Modelos de Jogo In: ELIAS, N. Introdução à Sociologia. Lisboa: Edições 70, p. 77-112, 1980.

. O processo civilizador: formação do estado e civilização. v. 2. Rio de Janeiro: Zahar, 1993. 
O processo civilizador: uma história dos costumes. v. 1. Rio de Janeiro: Zahar, 1990.

Para a fundamentação de uma teoria dos processos sociais $I n$ : ELIAS, N. Escritos \& Ensaios 1: estado, processo, opinião pública. Rio de Janeiro: Jorge Zahar, p. 197-231, 2006.

A sociedade dos indivíduos. Rio de Janeiro: Jorge Zahar, 1994.

FERNANDES, S. R. A. (Org.). Mudança de religião no Brasil: desvendando sentidos e motivações. São Paulo: Palavra e Prece, 2006.

FILORAMO, G.; PRANDI, C. As ciências das religiões. São Paulo: Palcos, 1999.

FINN T. From death to rebirth: ritual and conversion in antiquity. New York: Paulist Press, 1997.

FORACH, Marialice Mencarine; MARTINS, J, de Souza. Sociologia e sociedade. São Paulo: Livros Técnicos e Científicos, 1977.

FREITAS, Denis de; HOLANDA, Adriano Furtado. Conversão religiosa: buscando significados na religião. Rev. Interinst. Psicol., v. 7, n. 1, p. 93-105, Jun., 2014.

FRESTON, Paul. Breve história do pentecostalismo brasileiro In: ANTONIAZZI, Alberto et al. Nem anjos, nem demônios: interpretações sociológicas do pentecostalismo. Petrópolis, Vozes, 1994.

GIL, A. C. Métodos e Técnicas de Pesquisa Social. São Paulo: Atlas, 1999.

GILSON, Étienne. Introdução ao estudo de santo Agostinho. 2 ed. São Paulo: Discurso.Editorial, Paulus, 2010.

GLASSER, A. F. A ética calvinista e a ética protestante de Max Weber: aproximações e contrastes In: LIBERAL, M. M. C. de. Um olhar sobre ética e cidadania. Coleção Reflexão Acadêmica, v. 2. São Paulo: Universidade Presbiteriana Mackenzie, 2002.

As representações sociais do corpo e sexualidade no protestantismo brasileiro. Revista de Estudos da Religião, n. 1, p. 1-38, 2006.

Origens e imagens do protestantismo brasileiro do século XIX.

Revista Ciências da Religião: história e sociedade. v. 1, n. 1. São Paulo: Universidade Presbiteriana Mackenzie, 2003.

GOMES, A. M. de A. O Protestantismo presbiteriano e o ideal de progresso: o Mackenzie College e a formação do empresariado em São Paulo entre 1870 e 1914 In: Estudos da Religião: Revista Semestral de Estudos e 
Pesquisas em Religião, São Bernardo do Campo: Universidade Metodista de São Paulo, ano XIV, no 18, p. 145-171, jun. 2000.

. Um estudo sobre a conversão religiosa no protestantismo histórico e

na psicologia social da religião. Revista Mackenzie: Ciências e religião. Artigo 7, v. 9, n. 2, 2011.

GOMES, D. M. et al. Psicologia da Religião no Brasil: A produção em periódicos e livros. Psicologia: Teoria e Pesquisa. n. 25, v. 3, p. 441-446, 2009.

GRONINGEN, G. V. Revelação messiânica no Antigo Testamento. São Paulo: Cultura Cristã, 2003.

HAHN, C. J. História do culto protestante no Brasil. São Paulo: Aste, 1989.

HAPPEL, S.; WALTER, J. J. Conversion and discipleship: a christian foudation for ethics doctrine. Philadelphia: Fortress, 1986.

HEIDEGGER, M. Fenomenologia da vida religiosa. Petrópolis: Vozes, 2011.

HELM, P. The beginnings: word and spirit in conversion. Carlisle: Banner of Truth Trust, 1986.

HENNING, M. C.; Moré. C. L. O. O. Religião e psicologia: análise das interfaces temáticas. Revista de Estudos da Religião. n. 9, v. 4, p. 84-114, 2009.

HERVIEU-LÉGER, Danièle. O peregrino e o convertido: a religião em movimento. Petrópolis-RJ: Vozes, 1999.

HIPONA, Agostinho de. Confissões. 3. ed. São Paulo: Paulinas, 1984.

HODGE, C. Systematic theology. v. 3, New York: Scribner; Armstrong, 1877. . Teologia sistemática. São Paulo: Hagnos, 2001.

JAMES, W. As variedades da experiência religiosa: um estudo sobre a natureza humana. São Paulo: Cultrix, 1995.

JAPIASSU, Hilton; MARCONDES, Danilo. Dicionário Básico de Filosofia. 3.ed., Rio de Janeiro: Zahar, 1996.

JOHNSON, P. E. Psicologia da religião. São Paulo: Aste, 1964.

JUNG, C. G. Psicologia e Religião. Trad. Pe. Dom M. R. Rocha. Petrópolis: Vozes, 1978.

KIDDER, D. P.; FLETCHER, J. C. O Brasil e os brasileiros: esboço histórico e descritivo. Trad. Elias Dollianiti. v. 1 e 2. São Paulo: Companhia Editora Nacional, 1941. 
KREIDER, A. The change of conversion and the origin of Christendom. Harrisburg: Trinity Press, 1999.

KUHN, T. The Structure of Scientific Revolutions. 2 ed. Chicago University Press, 1972.

LANGEWIESCHE. K. Des conversions réversibles: etudes de cas dans le nord-ouest du Burkina Faso. v. 68, p. 47-65, Parcours de conversion. Journal des africanistes, 1968.

LEFEVRE, F.; LEFEVRE Ana Maria C.; TEIXEIRA, J.J.V. Depoimentos e Discursos. Brasília: Liberlivro, 2005.

. O discurso do sujeito coletivo. Caxias do Sul: Educs, 2000.

O discurso do sujeito coletivo. Desdobramentos. Caxias do Sul: Educs, 2003.

LEONARD, É. G. O Protestantismo brasileiro: estudo de eclesiologia e história social. São Paulo: ASTE, 1963.

LLOYD-JONES, D. M. Conversions: psychological and spiritual. London: InterVarsity Press, 1974.

. Conversões: psicológicas e espirituais. São Paulo: PES.

LÕWY, Michel. Redenção e utopia. São Paulo: Companhia das Letras, 1989.

LUTERO, M. Obras selecionadas: interpretação do Novo Testamento Gálatas e Tito. v. 10. São Leopoldo: Sinodal, 2008.

MACIEL, E. D. O drama da conversão: análise da ficção Batista. Rio de Janeiro: Cedi, 1988.

. O pietismo no Brasil: um estudo de sociologia da religião. 1972.

Tese de Doutorado em Ciências Humanas, Universidade de São Paulo, São Paulo, 1972.

MARIANO, Ricardo. Neopentecostalismo: sociologia do novo pentecostalismo no Brasil. São Paulo, Loyola, 1999.

MARX, K. Carta à K. Schmidt In: MARX, Karl \& ENGELS, Friedrich. A Comuna de Paris. Belo Horizonte, Aldeia Global, 1979.

MARX, Karl \& ENGELS, Friedrich. O Manifesto Comunista. 3 ed., São Paulo: Global, 1988.

MARX, Karl. A Guerra Civil na França. São Paulo: Global, 1986. 
A Questão Judaica. São Paulo: Moraes, 1978.

As Lutas de Classes na França. São Paulo: Global, 1986.

. Crítica da Filosofia do Direito de Hegel: Introdução In: Revista

Temas de Ciências Humanas. Vol. II. São Paulo, Grijalbo, 1978.

. Formações Econômicas Pré-Capitalistas. 4 ed., Rio de Janeiro: Paz e Terra, 1985.

. Manuscritos Econômicos-Filosóficos In: FROMM, Erich. Conceito Marxista do Homem. 8 ed., Rio de Janeiro: Zahar, 1983.

. O Capital. V. 2. 3 ed., São Paulo: Nova Cultural, 1988.

. O Dezoito Brumário e Cartas a Kugelmann. 5 ed., Rio de Janeiro: Paz e Terra, 1986.

. Proudhon In: MARX, Karl \& ENGELS, Friedrich. A Sagrada Família. Lisboa, Presença, 1979.

. Teses Sobre Feuerbach In: MARX, Karl \& ENGELS, Friedrich. A Ideologia Alemã. 3 ed., São Paulo: Ciências Humanas, 1982.

. Trabalho Assalariado e Capital. 4 ed., São Paulo: Global, 1987.

MARX, Karl; ENGELS, Friedrich. A sagrada família. São Paulo: Bomtempo, 2003.

MATOS, A. Os pioneiros presbiterianos do Brasil (1859- 1900):

missionários, pastores e leigos do século 19. São Paulo: Cultura Cristã, 2004.

MENDONÇA, A. G. O celeste porvir: a inserção do protestantismo no Brasil. São Paulo: Aste; Umesp, 1995.

MENDONÇA, A. G.; VELÁSQUEZ FILHO, P. Introdução ao protestantismo no Brasil. São Paulo: Loyola; Ciências da Religião, 1990.

MOSSIÈRE, G. Psychologie de la conversion: études sur l'influence inconsciente. Fribourg: Delval, 2007.

MOTAL, C. S.; TRADI, L. A. B.; BOASLL, M. J. V. B. V. O papel da experiência religiosa no enfrentamento de aflições e problemas de saúde. Rev. Interface: Comunicação, Saúde, Educação, v. 16, n. 42, p. 667, Botucatu, 2012.

MOULTON, H. K. The analytical Greek lexicon revised. Grand Rapids; Michigan: Zondervan, 1977.

NABUCO, Joaquim. Minha fé. Recife: Fundação Joaquim Nabuco, Massangana, 1985. 
. Minha formação. Brasília: Edições Câmara, 2019.

NOCK, A. D. Conversion: the old and the new in religion from Alexander of Hippo. London: Oxford University Press,1933.

OTTO, R. O sagrado. Petrópolis: Vozes, 2007.

PACKER, J. I. Entre os gigantes de Deus: uma visão puritana da vida cristã. São José dos Campos: Fiel, 1996.

PAIVA, G. J. de. Identidade e pluralismo: identidade religiosa em adeptos brasileiros de novas religiões japonesas. Revista Psicologia: teoria e pesquisa, Brasília, n. 20, p. 21-29, 2004. - Imaginário, simbólico e sincrético: aspectos psicológicos da filiação a novas religiões japonesas. Revista Psicologia: reflexão e crítica, Porto Alegre, v. 12, n. 2, p. 521-535, 1999.

PAIVA, G. J.; et al. Psicologia da Religião no Brasil: A produção em periódicos e livros. Psicologia: Teoria e Pesquisa, v. 25, n. 3, p. 441-446, 2009.

PARAVIDINIL, João Luiz Leitão; GONÇALVEZ, Márcio Antônio. Neopentecostalismo: desamparo e condição masoquista. Revista Mal-Estar Subjetividade, v. 9, n. 4, p. 1187-1188, Fortaleza, 2009.

PEACE, R. V. Conversion in the New Testament: Paul and the Twelve. Grand Rapids: W. B. Eerdmans, 1999.

PEREIRA, José Carlos. Espiritualidade da Paixão. São Paulo: Arte \& Ciências, 2002, p. 165.

PIERUCCI, Antônio Flávio. Religião como solvente: uma aula. Rev. Novos Estudos - CEBRAP, São Paulo, n. 75, p. 120, 2006.

PONTES, J. A. et al. Neopentecostalismo: a ressignificação mercadológica do pentecostalismo tradicional. Revista Unitas, v. 5, n. 1, p. 60-61, Vitória, 2017.

PRIEN, H. J. Formação da Igreja evangélica no Brasil. Petrópolis: Vozes, 2001.

RAD, G. V. Teologia do Antigo Testamento. v. 1 e 2. São Paulo: Aste, 1957.

RAMALHO, J. P. Prática educativa e sociedade: um estudo de sociologia da Educação. Rio de Janeiro: Zahar, 1976.

READ, W. R. Fermento religioso nas massas do Brasil. São Bernardo do Campo: Imprensa Metodista, 1967. 
RIBEIRO, B. A igreja presbiteriana no Brasil: da autonomia ao cisma. São Paulo: O Semeador, 1987.

. Igreja evangélica e república brasileira (1989-1930). São Paulo: 0 semeador, 1991.

. José Manoel da Conceição e a reforma evangélica. São Paulo: o semeador, 1995.

O padre protestante. 2. ed. São Paulo: Casa Editora Presbiteriana, 1979.

Protestantismo e cultura brasileira: aspectos culturais da implantação do protestantismo no Brasil. São Paulo: Casa Editora Presbiteriana,1981.

. Protestantismo no Brasil monárquico: aspectos culturais de aceitação do protestantismo no Brasil (1822-1888). São Paulo: Pioneira, 1973.

RIBEIRO, Fernanda Mendes Lages; MINAYO, Maria Cecília de Souza. O papel da religião na promoção da saúde, na prevenção da violência e na reabilitação de pessoas envolvidas com a criminalidade. Rev. Ciência \& Saúde Coletiva, v. 19 n. 6, p. 1785, Rio de janeiro, 2014.

ROCHA, Rodrigo Carlos da. Redes de sociabilidades neopentecostais: interfaces com a política e a cidadania. Disponível em:

<https://cchla.ufrn.br/shXVII/Anais/GT24/24.5.pdf>. Acesso em: 05 mar. 2020.

ROSA, Merval. Psicologia da religião. Rio de Janeiro: Casa Publicadora Batista, 1985.

SCHLESINGER, Hugo e PORTO, Humberto. Dicionário enciclopédico das religiões. v. 1, Petrópolis-RJ: Vozes, 1995.

SHOJI, R. Uma perspectiva analítica para os convertidos ao Budismo japonês no Brasil. Revistas Estudos da Religião, n. 2, p. 74-84, 2002.

SIQUEIRA, Deis. O labirinto religioso ocidental: da religião à espiritualidade. Do institucional ao não convencional. Soc. estado., Brasília, v. 23, n. 2, p. 425462, 2008. Doi: http://dx.doi.org/10.1590/S0102-69922008000200008.

Disponível em: <http://www.scielo.br/scielo.php?script=sci_arttext\&pid=S010269922008000200008\&lng=en\&nrm=iso >. Acesso em: 05 mar. 2020.

SPENER, P. J. Pia Desideria: um clássico do pietismo protestante. São Bernardo do Campo: Metodista, 1985.

STADTLER, H. Conversão ao Pentecostalismo e alterações cognitivas e de identidade. Revistas Estudos da Religião, n. 2, p. 85-111, 2002.

STARBUCK, E. D. The Psychology of Religion. London, 1910. 
STRONG, A. H. Systematic theology: three volumes in one. Philadelphia: The Judson Press, 1954.

SUCHMAN, M. C. Language and self-transformation: a study of the Christian conversion narrative. Cambridge: Cambridge University Press, 1992.

TEIXEIRA, A. A exterioridade de Deus: uma aproximação à teoria da religião de Régis Debray. Didaskalia, v. 38, n. 2, p. 455-481, 1 jun. 2008.

TOLSTÓI, Liev. Uma confissão. São Paulo, MC Mundo Cristão, 2017.

VALLE, E. Conversão: da noção teórica ao instrumento de pesquisa. Revistas Estudos da Religião, n. 2, p. 18-50, 2002.

VERGÍLIO, S. R. \& Holanda, A. F. Analogias e diferenças entre reuniões mediúnicas espíritas e o atendimento em psicologia clínica. Revista da Abordagem Gestáltica, v. 18, n. 2, p. 173-182, 2010.

VIANA, António Manuel Couto. Tesouro da poesia portuguesa:

Selecção, prefácio e notas. Lisboa: São Paulo: Verbo, 1984.

VIEIRA, D. G. O protestantismo, a maçonaria e a questão religiosa no Brasil. Brasília: Universidade de Brasília, 1980.

WEBER, Max. A Ética Protestante e o Espírito do Capitalismo. 5 ed. São Paulo: Pioneira, 1987.

Ciência e política: Duas vocações. São Paulo: Cultrix, 1999.

WHITEHEAD, E. Evelyn; WHITEHEAD, D. James. Comunidade de Fé: Como ser Cristãos neste Fim de Século. São Paulo: Ed. Loyola., 1995, p. 85-96.

WILLIAMS, R. Marxismo y cultura. Barcelona: Penisola, 1980. 